\title{
Scour effects on $p-y$ curves for shallowly embedded piles in sand
}

\author{
W. G. $\mathrm{QI}^{*} \dagger$, F. P. GAO $\dagger$, M. F. RANDOLPH* and B. M. LEHANE $\$$
}

\begin{abstract}
Soil scour around a shallowly embedded pile can significantly compromise its lateral response, reducing both stiffness and capacity. Estimation of the lateral pile response must take into account both the scour-hole geometry and the overconsolidation effects on the remaining soil. A series of centrifuge model tests with various scour profiles were conducted at a scale of 1:250 to investigate the effects of both local and general scour on the response of a laterally loaded pile. Measured pile moment distributions and force-displacement data at the pile head were used to derive $p-y$ curves quantifying the lateral pile-soil interaction. The $p-y$ curves derived from various scour profiles were compared for equivalent depths below the new scour base, and below the original soil surface. For the general scour cases, the $p-y$ curves for given depths below the post-scour surface are essentially identical to those at the same depths without scour. In contrast, for the local scour cases, the $p-y$ response at a given depth below the scour-hole base is much stiffer than at the same depth below the original soil surface. As a practical approach to evaluate the effects of scour, the concept of an effective soil depth is introduced to determine the corresponding $p-y$ curves for shallowly embedded piles in sand.
\end{abstract}

KEYWORDS: centrifuge modelling; deformation; erosion; piles \& piling; soil/structure interaction; stiffness

\section{INTRODUCTION}

Piles have been used widely for the foundations of offshore structures. The lateral response is commonly evaluated using a load transfer approach, with ' $p-y$ ' curves quantifying the non-linear interaction between the pile and the surrounding soil. The $p-y$ curves idealise the soil as a series of independent springs distributed along the pile length, with each spring describing the non-linear relationship between the lateral soil resistance $(p)$ and the lateral deflection of the pile (y). Various formulations for $p-y$ curves have been developed for sands, for example Reese et al. (1974) and O'Neill \& Murchison (1983), which form the basis of the widely used API method (API, 2011), and a recent approach based on cone penetration data (Suryasentana \& Lehane, 2014).

Scour around submarine structures leads to a reduction in the effective stresses and hence strength and stiffness of the soil at a given depth around a pile; such scour can be significant and compromise the safety of structures (Hoffmans \& Verheij, 1997; Sumer \& Fredsøe, 2002). It is noted that scour effects have not been well reflected in existing $p-y$ curve methods, although the problem has been studied using numerical analysis (Lin et al., 2010, 2014).

Two types of scour have been identified: 'general scour' where the elevation of the soil surface is reduced globally due to erosion of the whole superficial soil layer; and 'local scour' where the disturbed flow around a structure such as a foundation pile leads to the formation of a conical scour pit around the object. A number of empirical equations for estimating local scour depth have been proposed for various soils and hydrodynamic conditions (Melville \& Sutherland,

Manuscript received 28 July 2015; revised manuscript accepted 19 February 2016. Published online ahead of print 30 March 2016. Discussion on this paper closes on 1 January 2017, for further details see p. ii.

* Centre for Offshore Foundation Systems, University of Western Australia, Crawley, Australia.

$\dagger$ Key Laboratory for Mechanics in Fluid Solid Coupling Systems, Institute of Mechanics, Chinese Academy of Sciences, Beijing, People's Republic of China.

\$ School of Civil and Resource Engineering, University of Western Australia, Crawley, Australia.
1988; Sumer et al., 1992; Richardson \& Davis, 2001; Zanke et al., 2011; Qi \& Gao, 2014a). Flume tests for local scour depth around a pile in combined waves and current (Qi \& Gao, 2014b) and field scour data from operating European wind farms (Matutano et al., 2013) indicate that the normalised local scour depth around piles $S / D$ (where $S$ is the scour depth and $D$ is the pile diameter) could be up to 1.5 or even higher.

Scour can have a significant effect on the lateral response of piles such as the large-diameter monopiles employed for offshore wind turbines. As scour depth is predicted to scale with the pile diameter, scouring can have a great impact on the overall response of these monopiles, as their length to diameter ratios are relatively small (typically between about 3 and 10). As shown in Fig. 1, the scour reduces the pile embedment depth from $L$ to $L^{\prime}$ and increases the load eccentricity from $e$ to $e^{\prime}$, inducing much larger deformations of the pile and changing the profiles of lateral soil resistance $p$.

Scour will cause the $p-y$ response at a given absolute depth $z$ (measured from the original soil surface or 'mudline') to soften, reducing both initial stiffness and the limiting resistance. However, $p-y$ curves are generally expressed as a function of the current (i.e. post-scour) depth $z^{\prime}$ (Fig. 1), for which the new $p-y$ response will improve relative to the original response at the same depth in an unscoured profile.

For general scour conditions, the overconsolidation induced by the removal of a complete layer of soil changes the in situ soil state and thus may affect the $p-y$ response at a given depth, $z^{\prime}$. For local scour conditions, in addition to any overconsolidation effect, the lateral soil resistance at a given depth below the base of the scour hole is enhanced by the presence of soil above the scour level, remote from the pile (Lin et al., 2014).

Scour effects for laterally loaded piles in sand have been studied analytically and numerically (Lin et al., 2010, 2014). General scour effects were incorporated by updating the parameters at a given depth, $z^{\prime}$, to account for the overconsolidation induced by removal of a height, $S$, of sand while local scour effects were included by modifying the lateral resistance due to changes in the shallow wedge-type failure mechanism. Their numerical results indicated that the local scour hole would result in much higher lateral soil resistance 

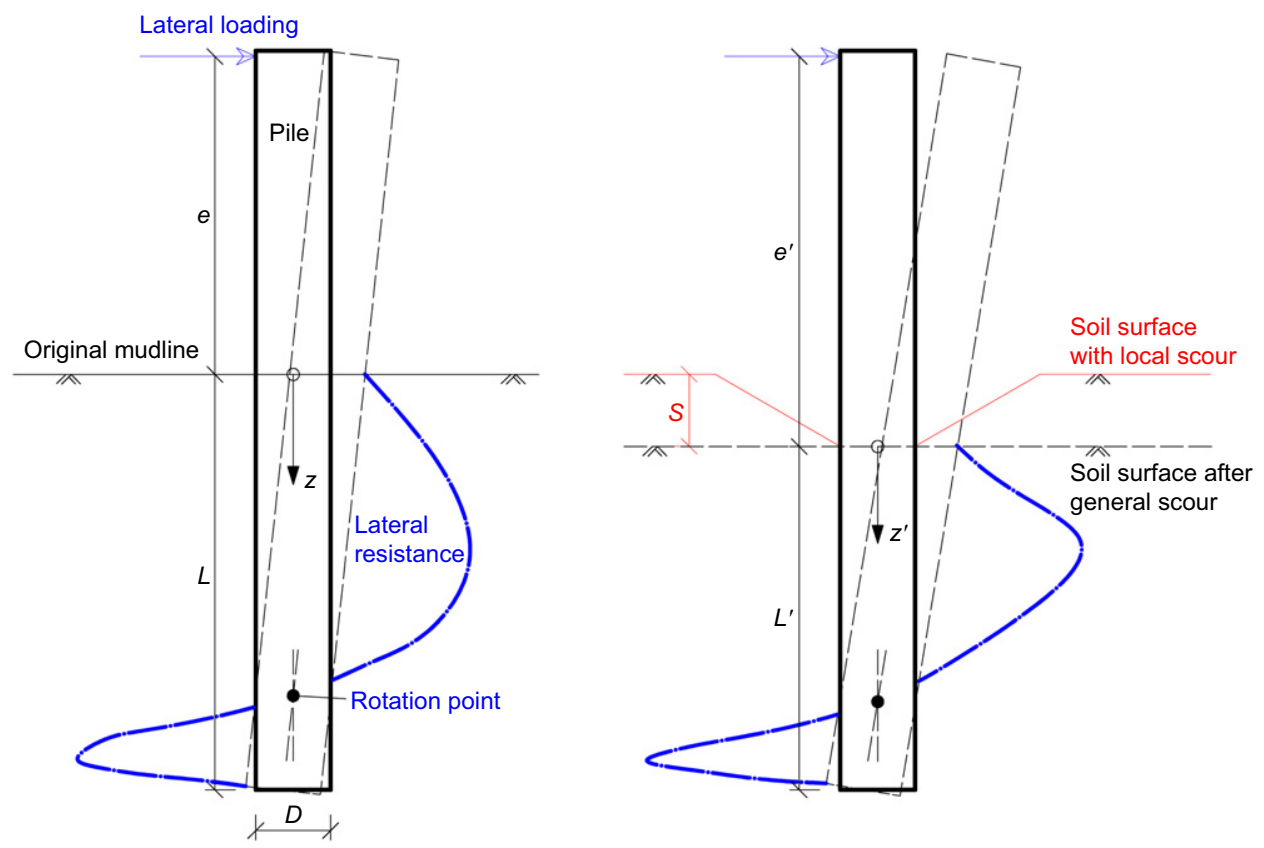

Fig. 1. Illustration of scour effect on the lateral response of a shallowly embedded pile

for a given (post-scour) depth $z^{\prime}$ than for the general scour case, that is, complete removal of the soil surface layer.

Experimental data regarding scour effects on the lateral pile response are relatively scarce. The present paper reports a series of centrifuge model tests conducted to investigate scour effects on the lateral pile-soil interaction. Based on the measured bending moment distributions along the model pile in a scour hole, $p-y$ curves were derived and analysed to evaluate the effects of both general and local scour for shallowly embedded piles.

\section{EXPERIMENTAL SET-UP FOR CENTRIFUGAL MODELLING \\ Overview}

The experiments were performed in the drum geotechnical centrifuge at the University of Western Australia (UWA) at 250 times the gravitational acceleration (i.e. $250 \mathrm{~g}$ ). The UWA drum centrifuge has an outer diameter of $1.2 \mathrm{~m}$, an inner diameter of $0.8 \mathrm{~m}$ and a channel width of $0.3 \mathrm{~m}$ (Stewart et al., 1998). The $g$-level increases with radius and the reference position of the $250 \mathrm{~g}$-level was chosen to be at one-third of the model pile penetration depth (Taylor, 1995; Klinkvort et al., 2013). The maximum error in the stress profile of the soil compared with the corresponding prototype condition is very small, generally less than $4 \%$.

The lateral load at the pile head $(H)$ was imposed by vertical movement of the tool table inside the drum centrifuge and monitored by strain gauges on the loading arm. The lateral displacement of the pile at the loading position $\left(y_{\mathrm{L}}\right)$ was monitored from the vertical motor encoders, whose accuracy is approximately $3 \times 10^{-5} \mathrm{~mm}$ (Stewart \& Randolph, 1991). Since the loading arm attached to the vertical actuator had a finite stiffness, the value of $y_{\mathrm{L}}$ is significantly smaller than the actuator movement monitored from the vertical motor encoders, and a correction was later applied to the actuator movement to account for flexure of the loading arm. The sampling frequency of the tests was set at $10 \mathrm{~Hz}$. All tests were conducted under displacement control at a velocity of $v=0.015 \mathrm{~mm} / \mathrm{s}$, which was sufficient to ensure drained conditions in the sand $\left(v D / c_{\mathrm{v}}<10^{-4}\right.$, where $c_{\mathrm{v}}$ is the sand consolidation coefficient of around $500 \mathrm{~mm}^{2} / \mathrm{s}$ ). A camera was

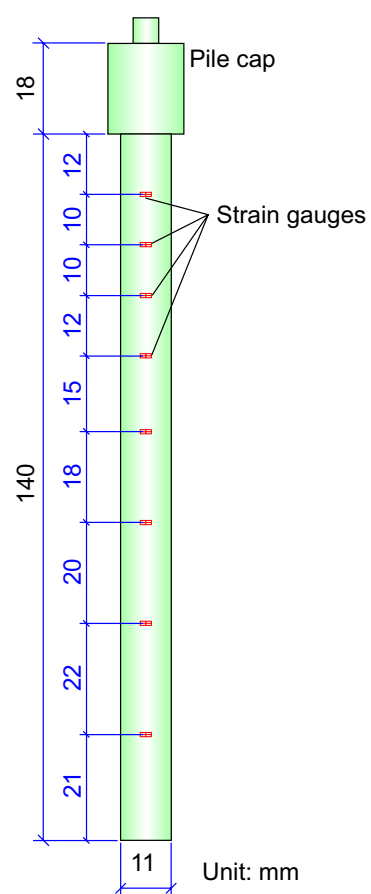

(a)

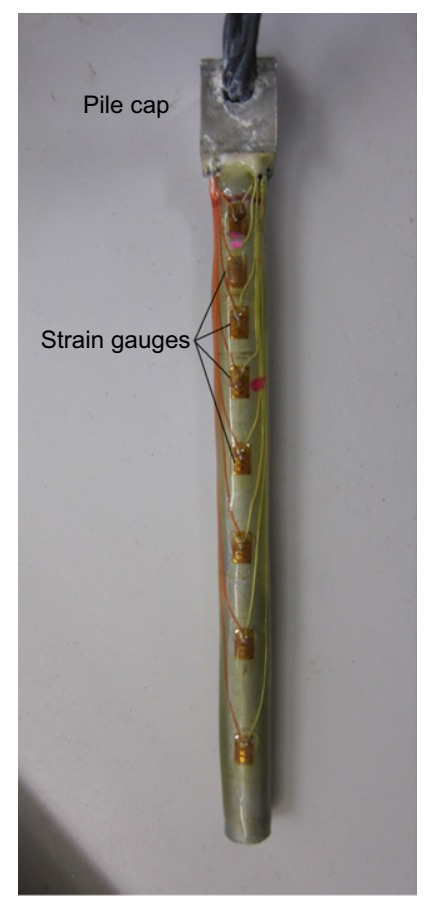

(b)
Fig. 2. Model pile: (a) schematic diagram; (b) photograph

utilised to monitor the whole process. Note that in this paper, all the data are expressed in prototype values according to the usual scaling laws (Taylor, 1995; Dyson \& Randolph, 2001).

\section{Model pile}

The model pile was open-ended and fabricated from a hollow, circular, aluminium tube with an outer diameter of $10 \mathrm{~mm}$ and a wall thickness of $1 \mathrm{~mm}$ (refer to Guo et al., 2014). The pile was instrumented with eight levels of strain gauges, calibrated for measuring bending moment. The strain gauges were spaced relatively densely for the shallow pile segment, gradually becoming more sparse with increasing pile depth (see Fig. 2). The layout helped target pile-soil 
Table 1. Index properties of UWA silica sand (after Cheong, 2002; Schneider \& Lehane, 2006)

\begin{tabular}{l|c|c|c|c|c}
\hline $\begin{array}{c}\text { Mean size of sand } \\
\text { grains, } d_{50}: \mathrm{mm}\end{array}$ & $\begin{array}{c}\text { Specific } \\
\text { gravity, } G_{\mathrm{s}}\end{array}$ & $\begin{array}{c}\text { Maximum } \\
\text { void ratio, } e_{\max }\end{array}$ & $\begin{array}{c}\text { Minimum } \\
\text { void ratio, } e_{\min }\end{array}$ & $\begin{array}{c}\text { Average relative } \\
\text { density, } D_{\mathrm{r}}\end{array}$ & $\begin{array}{c}\text { Buoyant unit weight } \\
\text { of soil, } \gamma^{\prime}: \mathrm{kN} / \mathrm{m}^{3}\end{array}$ \\
\hline 0.20 & 2.65 & 0.76 & 0.49 & 0.68 \\
\hline
\end{tabular}

interaction at shallow depths, where the influence of scour was expected to be greatest. A $0 \cdot 5-\mathrm{mm}$-thick layer of epoxy was coated on the wall of the model pile to protect the strain gauges, making an effective outer pile diameter $(D)$ of $11 \mathrm{~mm}$. Although the epoxy coating provides a relatively smoother surface than a prototype steel or concrete pile, this should not affect the relativities of the $p-y$ responses before and after scour. The tests were conducted at $250 \mathrm{~g}$, and thus modelled an equivalent prototype pile with diameter $D$ of $2.75 \mathrm{~m}$ and bending stiffness EI of $88 \cdot 1 \mathrm{GN} \mathrm{m}^{2}$. The total length of the pile was $140 \mathrm{~mm}$ ( $35 \mathrm{~m}$ at prototype scale).

The ratio of pile diameter to particle size of the sands ( $D / d_{50}$, where $d_{50}$ denotes the mean size of sand grains) for the tests was approximately 55, which is close to the target of 60 suggested by Remaud (1999), where grain size effects become negligible for laterally loaded piles (see Garnier et al., 2007).

\section{Soil preparation and characterisation}

The centrifuge model tests were conducted using fine silica sand, widely used at UWA, with index properties summarised in Table 1 . Sand was deposited in flight (at 20g) by dry pluviation to the full channel depth of $175 \mathrm{~mm}$. The sand was saturated, and then drained, from its base at $50 \mathrm{~g}$ inducing suction within the sand to keep it stable after halting the centrifuge. With the centrifuge stopped, the soil surface was carefully levelled to obtain an overall sand thickness of $170 \mathrm{~mm}$ (representing a prototype soil bed at $250 \mathrm{~g}$ of $42.5 \mathrm{~m}$ ) at the start of the testing programme. Local scour holes were excavated from that level of sand (as described later), while general scour conditions were simulated by scraping additional sand from the entire surface. The $g$-level was increased to $250 \mathrm{~g}$ to conduct each load test.

For soil characterisation, two cone penetration tests (CPTs) were performed 'in flight' prior to the pile tests using a $6 \mathrm{~mm}$ dia. cone $\left(d_{\text {cone }}=6 \mathrm{~mm}\right)$. The profiles of cone penetration end resistance $\left(q_{\mathrm{c}}\right)$ measured in these tests are plotted on Fig. 3(a) and may be represented by the following second-order polynomial

$$
q_{\mathrm{c}}=0.025 z^{2}+0.9 z(\mathrm{MPa})
$$

where $z$ (in metres) represents the penetration depth of the cone.

The relative density $D_{\mathrm{r}}$ was estimated from the measured cone tip resistance using the following correlation established by Schneider \& Lehane (2006) for the same sand in previous drum centrifuge tests at UWA, assuming deep cone penetration

$$
D_{\mathrm{r}}=\sqrt{\frac{q_{\mathrm{c}} / \sigma_{\mathrm{v} 0}^{\prime}}{250}}
$$

where $\sigma_{\mathrm{v} 0}^{\prime}$ is the vertical effective stress. Apart from at very shallow depths ( $z / d_{\text {cone }} \leq 3$, or $z \leq \sim 5 \mathrm{~m}$ in prototype) when equation (2) is not applicable, estimated relative densities are seen on Fig. 3(b) to be in the range of $0.68 \pm 0 \cdot 1$, namely medium-dense to dense consistency, with a trend of increasing density with depth. The relative density is about 0.68 at a depth of $15 \mathrm{~m}$, which is approximately half the initial pile embedment.

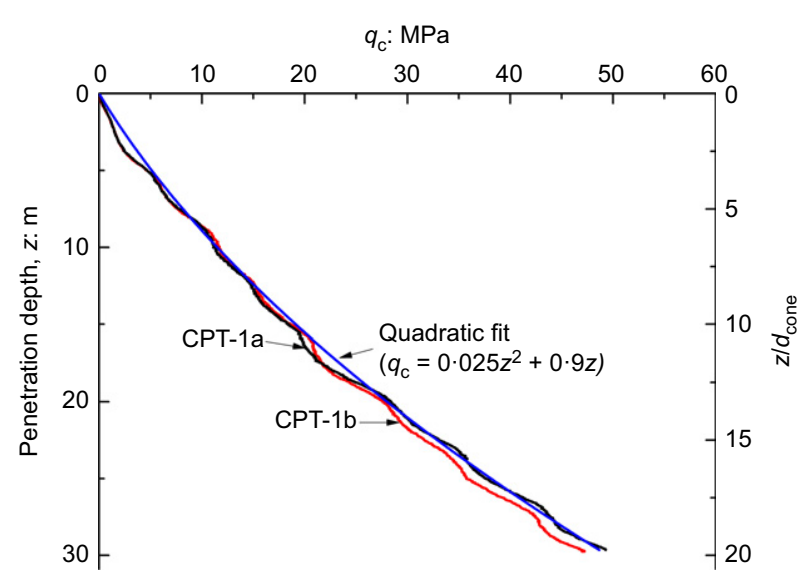

(a)

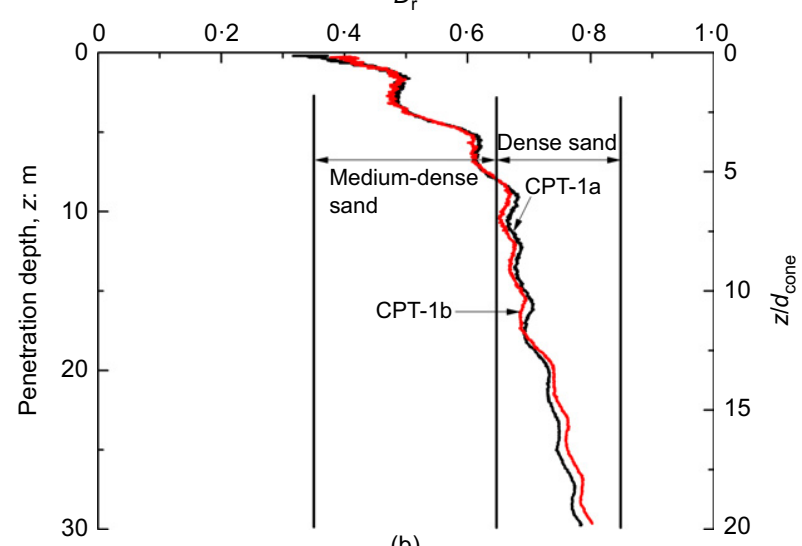

(b)

Fig. 3. Results of cone tests prior to any scour: (a) tip resistance; (b) calculated relative density

In addition to deriving $D_{\mathrm{r}}$ values from the cone resistance, the average (relative) density of the soil was estimated using two methods: (a) direct calculation of the density from the net weight of the dry sand rained into the drum and the volume of this sand immediately after preparing and levelling the sand surface and $(b)$ density values measured from tube samples taken from different locations within the drum centrifuge after all the tests were finished. The values from these two methods were generally consistent with each other $\left(D_{\mathrm{r}}=0.68\right)$ and also with the value deduced from the cone tests at $15 \mathrm{~m}$ soil depth (Fig. 3(b)).

\section{Scour hole excavation}

For the tests with local scour, a scour hole was created in the shape of an inverted circular cone. A scour hole slope of $30^{\circ}$ was adopted, which is in line with experimental results of Roulund et al. (2005) and recommendations of Hoffmans \& Verheij (1997). Three different maximum scour depths were modelled: $2.5 \mathrm{~m}, 5.0 \mathrm{~m}$ and $7.5 \mathrm{~m}$ at prototype scale.

Conical scour holes (local scour) were excavated at $1 \mathrm{~g}$ using the specially designed device shown in Fig. 4(a). First, 


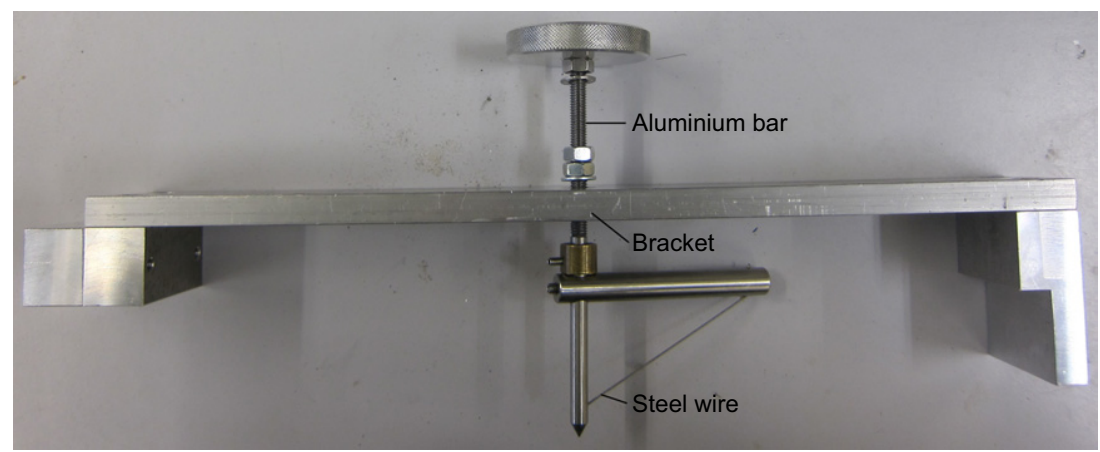

(a)

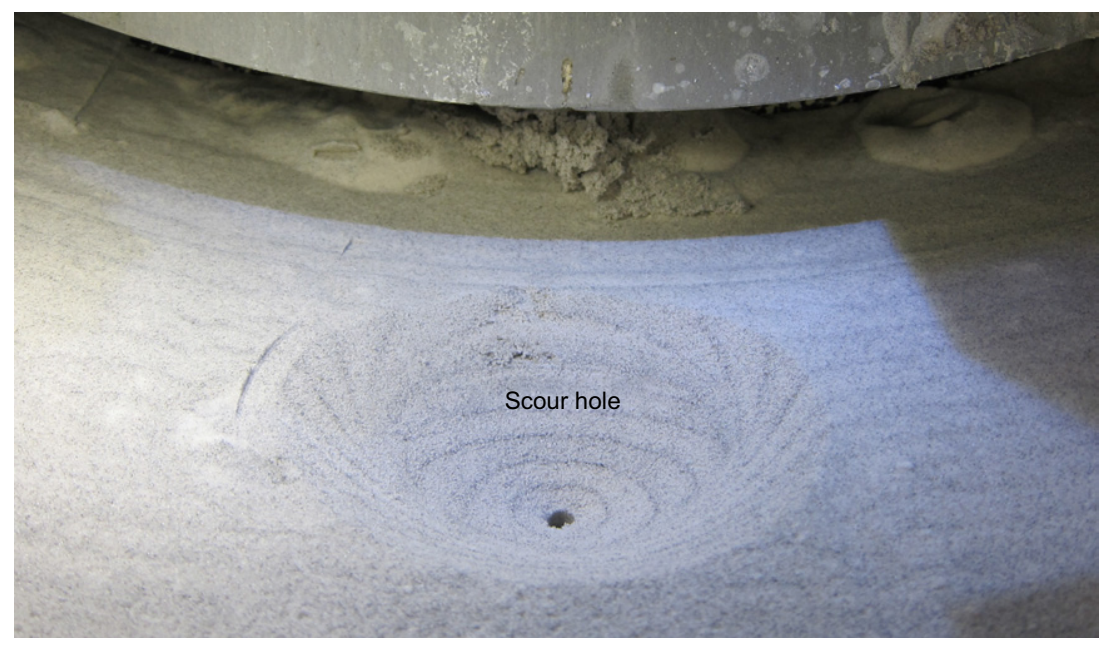

(b)

Fig. 4. Photographs of (a) scour hole scraper; (b) excavated $30 \mathrm{~mm}$ deep scour hole

Table 2. Programme of CPTs

\begin{tabular}{l|l|c|c|l}
\hline Test name & Scour type & Scour depth: $\mathrm{m}$ & Test position & Description \\
\hline CPT-1a & No scour & - & - & Benchmark CPTs for soil characterisation \\
CPT-1b & No scour & - & - & CPTs for the maximum scour hole $(S=7 \cdot 5 \mathrm{~m})$ \\
CPT-2 & Local scour & $7 \cdot 5$ & Edge of scour hole & Midpoint between scour \\
CPT-3 & Local scour & $7 \cdot 5$ & edge and scour centre & \\
& & $7 \cdot 5$ & Centre of scour hole & Repeated tests for general scour with $S=2 \cdot 5 \mathrm{~m}$ \\
CPT-4 & Local scour & $2 \cdot 5$ & - & Repeated tests for general scour with $S=5 \cdot 0 \mathrm{~m}$ \\
CPT-5a & General scour & $2 \cdot 5$ & - & Repeated tests for general scour with $S=7 \cdot 5 \mathrm{~m}$ \\
CPT-5b & General scour & $5 \cdot 0$ & - & \\
CPT-6a & General scour & $5 \cdot 0$ & - & \\
CPT-6b & General scour & $7 \cdot 5$ & $7 \cdot 5$ &
\end{tabular}

the soil was prepared and saturated during centrifuge spinning (see the following section for details). After soil preparation, suction was induced in the sand to keep it stable when the centrifuge was halted by draining water from the base of the channel while the centrifuge was spinning at $50 \mathrm{~g}$. With the centrifuge at rest, the designed device was positioned accurately and attached firmly to the upper wall of the centrifuge. By rotating the aluminium bar located at the centre of the bracket, the steel wire attached in the manner shown in Fig. 4(a) cut the (damp) sand enabling creation of the scour hole; see Fig. 4(b). The depth of the scour hole was varied by adjusting the aluminium bar. Note that the vertical orientation of the sand surface resulted in the excavated sand falling to the bottom of the centrifuge channel, from where it was removed manually.
Each scour hole was created immediately prior to jacking the model pile at $1 \boldsymbol{g}$ and just before spinning up the centrifuge back to $250 \mathrm{~g}$. An additional scour hole was prepared to facilitate CPTs in the deepest scour hole $(7.5 \mathrm{~m}$ prototype scale), as described later.

\section{Testing programme}

The testing programme comprised 11 CPTs (see Table 2) and seven monotonic laterally loaded pile tests (see Table 3), with all tests conducted at a centrifuge acceleration level of $250 \mathrm{~g}$. The spacing between adjacent tests was maintained at $150 \mathrm{~mm}$ (model scale), which was deemed sufficient to eliminate any significant influence between tests. 
Table 3. Programme of monotonic pile tests

\begin{tabular}{l|c|c|l}
\hline Test name & Embedment depth: $\mathrm{m}$ & Load eccentricity: $\mathrm{m}$ & Scour type \\
\hline Pile-1 & $31 \cdot 25$ & $5 \cdot 5$ & No scour \\
Pile-2 & $28 \cdot 75$ & $8 \cdot 0$ & Local scour \\
Pile-3 & $26 \cdot 25$ & $10 \cdot 5$ & Local scour \\
Pile-4 & $23 \cdot 75$ & $13 \cdot 0$ & Local scour \\
Pile-5 & $31 \cdot 25$ & $5 \cdot 5$ & General scour \\
Pile-6 & $31 \cdot 25$ & $5 \cdot 5$ & General scour \\
Pile-7 & $31 \cdot 25$ & $5 \cdot 5$ & General scour \\
\hline
\end{tabular}

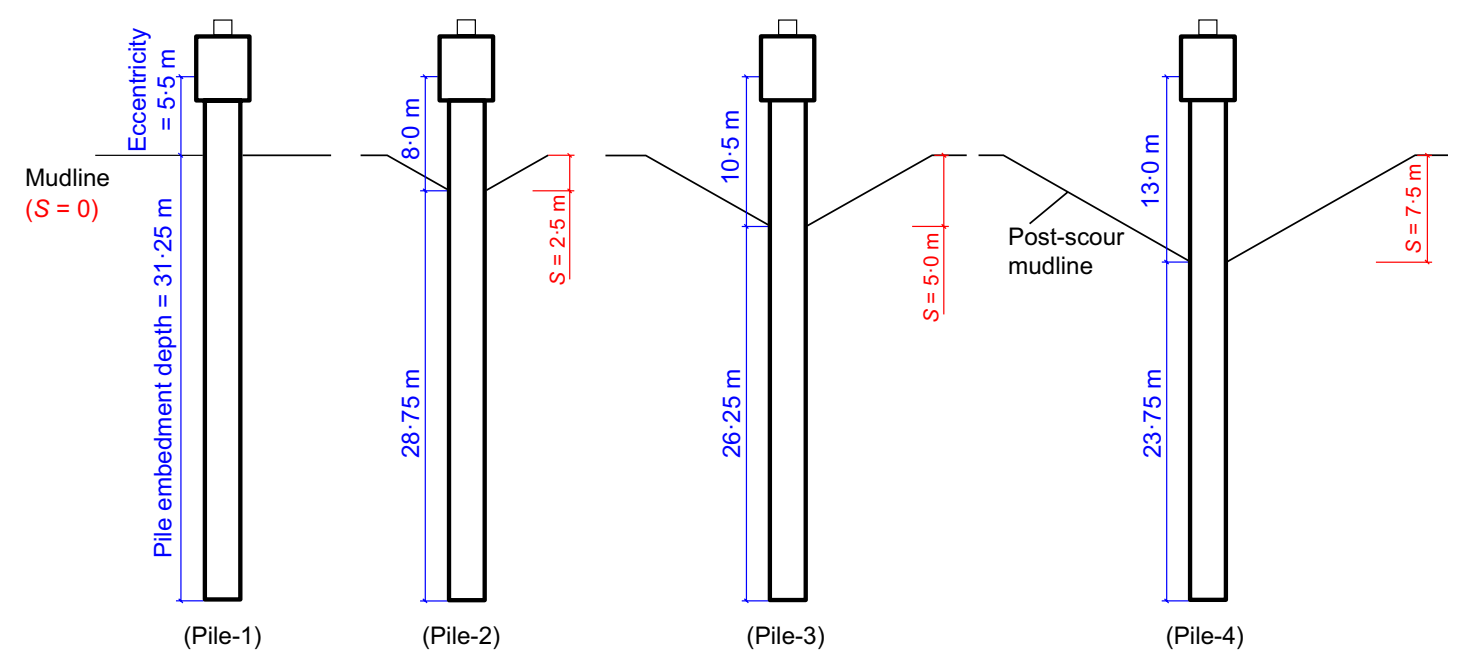

(a)

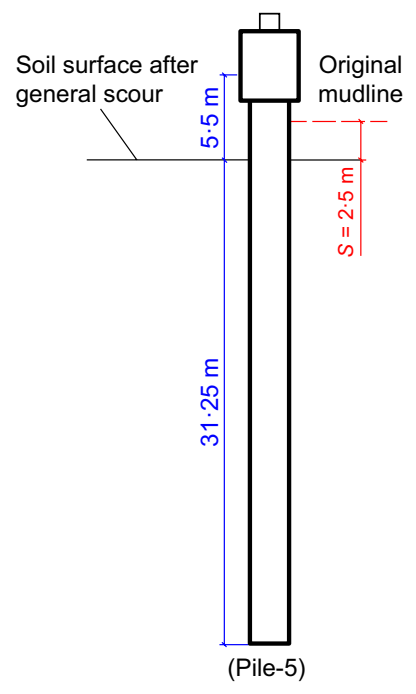

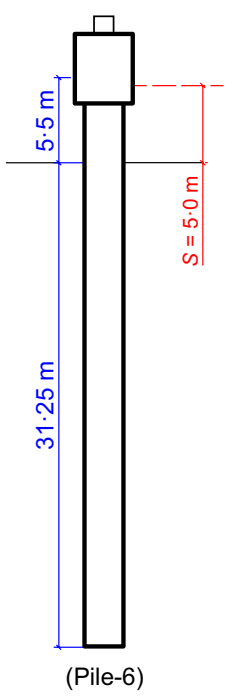

(b)

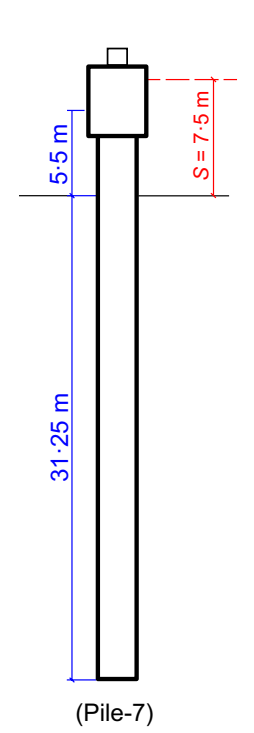

Fig. 5. Illustration of testing programme for the pile with (a) local scour and (b) general scour

Initially, two cone tests (CPT-1a and 1b) were carried out prior to any pile testing. Three cone tests (CPT-2, 3 and 4) were performed in and adjacent to a $7.5 \mathrm{~m}$ deep scour hole to examine the effects of local scour on the profile of cone resistance before the pile tests. After completion of the cone and pile testing with the soil surface at the original level, the soil level was lowered in three stages to simulate general scour. Pairs of cone tests (see Table 2) were conducted at each stage prior to the corresponding pile test.

The seven monotonic laterally loaded pile tests had the configurations shown schematically in Fig. 5 and were performed in the sequence given in Table 3 . The effects of local scour and general scour were assessed for scour depths of (approximately) one, two and three pile diameters. For the tests with local scour, the pile tip depth was maintained constant, so that the pile embedment and load eccentricity varied with scour depth. In contrast, both the embedment and eccentricity were kept constant for the tests with general scour (see Fig. 5).

Following creation of a scour hole (where relevant), each pile was pushed into the given soil location at $1 \mathrm{~g}$ using an actuator at a rate of $1 \mathrm{~mm} / \mathrm{s}$. Although no disturbance or heave of the soil was observed, a slight gap was visible between the pile and the damp sand (see Fig. 6). The gap appeared to close as the centrifuge was accelerated and the sand re-saturated. The cap at the head of the pile transferred 


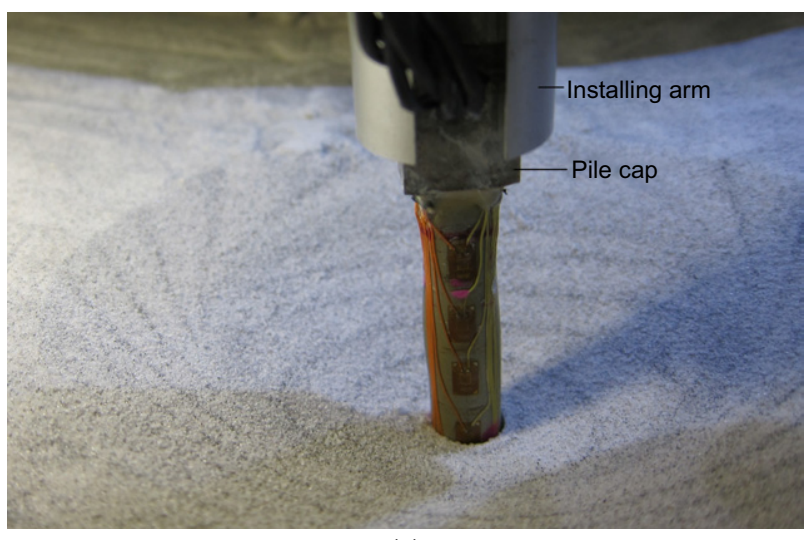

(a)

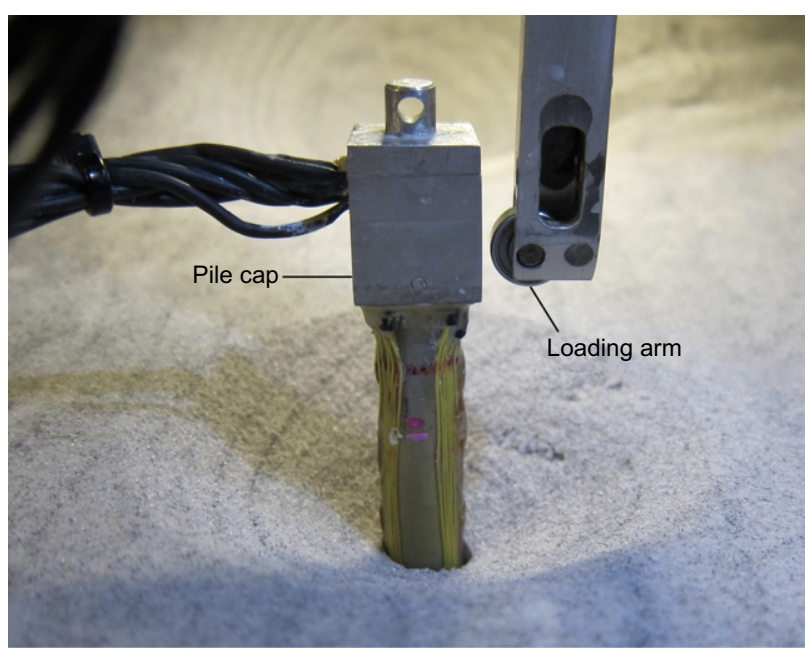

(b)

Fig. 6. Photographs of: (a) pile installation; (b) loading arrangement at pile head

the applied displacement from the actuator and provided guidance to achieve vertical installation; see Fig. 5(a).

As seen on Fig. 6(b), the installing arm was removed following pile installation to enable positioning of the lateral loading arm. The channel was spun up to $50 \mathrm{~g}$ and the soil was saturated by gradually drawing water into it from the channel base. As soon as saturation was complete, with water evident at the soil surface, the centrifuge was further accelerated to $250 \mathrm{~g}$. Once conditions had stabilised, lateral displacement was applied to the pile head at a rate of $0.015 \mathrm{~mm} / \mathrm{s}$ and the test continued until the loading arm reached its maximum design load.

After the benchmark test (pile-1) and all the tests with local scour (pile-2, 3, 4) were completed, a $10 \mathrm{~mm}$ layer of soil was scraped from the soil surface (at $1 \mathrm{~g}$ ) to simulate a general scour depth of $2.5 \mathrm{~m}$ (prototype scale). Two cone tests (CPT-5a and $5 \mathrm{~b}$, with details given in Table 2) were conducted prior to positioning and testing pile-5. The process was repeated for tests pile- 6 and pile-7 at increased levels of general scour.

The experimental data from two tests (pile-2 and pile-5) were excluded in the subsequent analysis because of unacceptable experimental inaccuracies arising from a relatively high imbalance of the spinning drum, as well as issues with the data acquisition system.

\section{RESULTS OF CONE TESTS}

\section{General scour cases}

Throughout the paper, $z$ denotes soil depth relative to the pre-scour mudline, while $z^{\prime}$ denotes soil depth below the
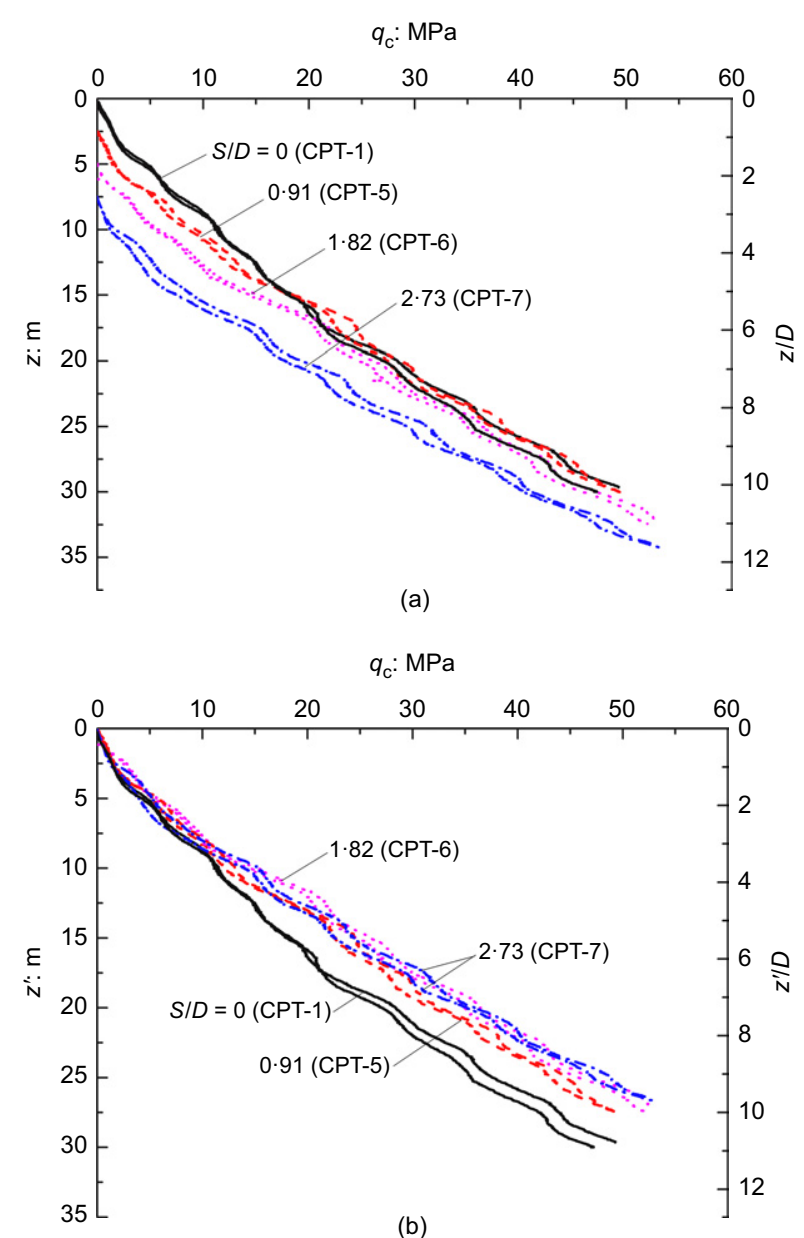

Fig. 7. Soil resistance profiles for various values of the general scour depth: (a) soil depth relative to original mudline; (b) soil depth below current scour base

current scour base (i.e. $z^{\prime}=z-S$, see Fig. 1). For cases without scour, $z^{\prime}$ is equivalent to $z$.

The CPT $q_{\mathrm{c}}$ profiles measured for a range of scour depths are shown in Fig. 7. The soil depth relative to the pre-scour mudline $(z)$ and the soil depth below the scour base $\left(z^{\prime}\right)$ are used as the vertical axes in Figs 7(a) and 7(b), respectively. It is shown that, although there is some convergence of the cone resistance profiles for a given absolute depth, $z$, closer agreement is obtained when plotted against the current (post-scour) depth, $z^{\prime}$, particularly for cases with $S=2.5 \mathrm{~m}$ and $5.0 \mathrm{~m}$. The lower cone resistances mobilised at depths greater than $10 \mathrm{~m}$ prior to any scour (CPT-1) reflect some gradual densification of the soil during the course of carrying out the first four pile tests, with the centrifuge having to be halted between each test to create a new scour hole and extract and re-install the instrumented pile.

The similarity in cone resistance for the soils at the same depth below the scour base $\left(z^{\prime}\right)$ suggests that significant horizontal stresses (on which the cone resistance depends, Houlsby \& Hitchman, 1988) have not been retained in the soil. This result may be influenced by the necessity to halt the centrifuge, allowing stresses to be relieved, to create each level of general scour. That process may have reduced the apparent degree of overconsolidation resulting from general scour.

For the three levels of general scour (nominally 1,2 and $3 D$ ) the average overconsolidation ratio in the critical zone of one to three pile diameters below the scour base would have ranged between 1.5 and $2 \cdot 5$, potentially resulting in 


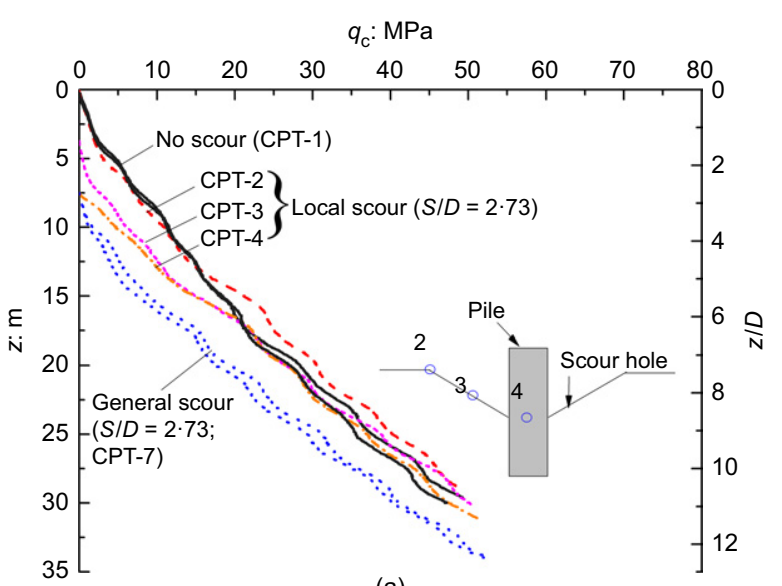

(a)

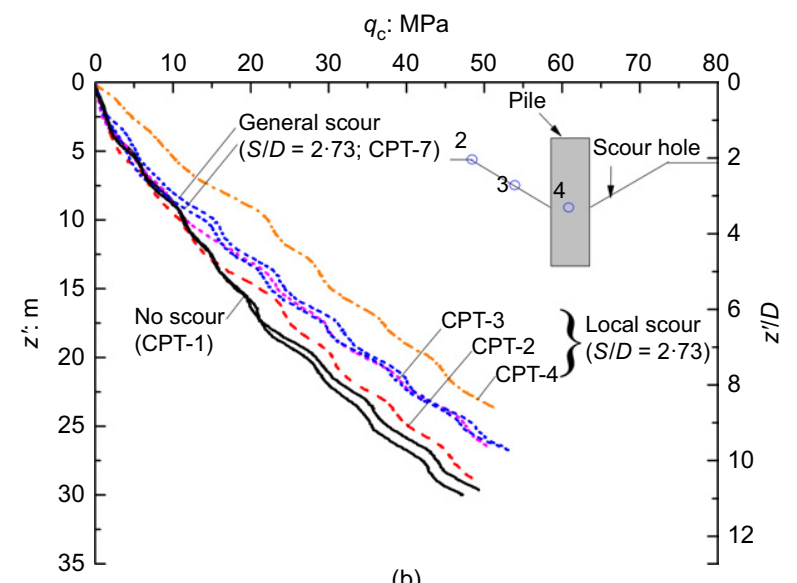

(b)

Fig. 8. Soil resistance profiles at different locations of $7 \cdot 5 \mathrm{~m}$ deep scour hole: (a) soil depth relative to original mudline; (b) soil depth below current scour base

horizontal stress increases by factors of around $1 \cdot 2$ to $1 \cdot 6$. However, for the size of cone used $(1.5 \mathrm{~m}$ diameter at prototype scale), surface effects may dominate over the relevant depth range, resulting in greater influence of the vertical, rather than horizontal, effective stress. Although it is difficult to quantify the effect of stopping and starting the centrifuge, it is conservative to take the results of Fig. 7 at face value. These suggest that the effect of general scour on the cone resistance profiles is minimal.

\section{Local scour cases}

The measured soil resistance profiles at different locations relative to a $7.5 \mathrm{~m}$ deep scour hole are shown in Fig. 8, compared with those for the flat bed case without scour (CPT-1a) and $7 \cdot 5 \mathrm{~m}$ of general scour case (CPT-7). Note that no pile was installed in these scour holes, and the pile illustrated in Fig. 8 is purely schematic. The soil depth relative to the original pre-scour soil surface $(z)$ and the soil depth below the scour surface $\left(z^{\prime}\right)$ at the particular CPT location are used as the vertical axis in Figs 8(a) and 8(b), respectively.

At the edge of the scour hole (CPT-2), the soil resistance remains essentially unchanged. However, within the scour hole (CPT-3 and CPT-4), especially at the centre of the scour hole (CPT-4), the cone resistance at a given depth $z^{\prime}$ becomes greater compared with the original bed before scour (e.g. compare CPT-4 and CPT-7), reflecting an influence of the sloping overburden in CPT-4.

\section{CENTRIFUGE TEST RESULTS}

Based on the bending moment distribution with depth determined from the strain gauges, $p-y$ curves can be obtained by differentiation and integration according to

$$
\begin{aligned}
& p=\frac{\mathrm{d}^{2} M}{\mathrm{~d} z^{2}} \\
& y=\iint \frac{M}{E_{\mathrm{p}} I_{\mathrm{p}}} \mathrm{d} z \mathrm{~d} z
\end{aligned}
$$

To limit the inaccuracy in determining $p$ by differentiating $M$ twice, the piecewise polynomial curve-fitting method was adopted (Yang \& Liang, 2006). When using this method, five successive moment data points were fitted to a third-order polynomial using a least-square method. The third-order polynomial was then differentiated twice and the soil response $p$ evaluated at the central data point. The soil response for the uppermost and lowermost three points were obtained from third-order polynomials fitted to the highest and lowest data points, respectively.

The lateral deflection of pile $y$ was calculated by integrating the bending moment twice as shown in equation (3b). Two integration constants $C_{1}$ and $C_{2}$ were determined from the measured displacement at the loading position and an assumed zero deflection condition at the point with zero lateral resistance (Wang \& Qi, 2008).

The bending moment distributions and corresponding deduced distributions of soil resistance and lateral pile deflection for test pile-1 are shown in Fig. 9. The pile generally exhibits a somewhat stiff behaviour, with significant displacement of the pile tip away from the loading direction. The locations of maximum bending moment and zero pile deflection get deeper as the lateral load increases.

The $p-y$ curves were obtained by combining the soil resistance and displacement curves at discrete intervals to produce curves for each depth, as shown in Fig. 10. Absolute values are plotted, but with the curves for depths of 5, 6 and $7 \mathrm{~m}$ reflecting negative values of $p$ and $y$. The stiffness of the $p-y$ curves experiences a rapid increase with soil depth for $z / D \leq 4$, whereas the difference between the $p-y$ curves becomes much smaller for depths of $z / D>4$.

The lateral load-displacement relationship at the loading position of the pile observed in the centrifuge test without scour (i.e. test pile-1) is plotted using prototype units in Fig. 11(a). The lateral pile deflection measured at the loading position is denoted by $y_{\mathrm{L}}$. The lateral pile deflection increases almost proportionally with lateral load, with no sign of an ultimate lateral capacity of the pile being reached even for deflections of about $0.06 \mathrm{D}$ at ground level (see Fig. 9(c)). The maximum pile displacement shown in Fig. 11(a) is deemed sufficient for many practical purposes considering, for example, the strict deformation criteria applied to offshore monopile foundations (Kuo et al., 2011) and the importance of lateral stiffness at low deformations for the dynamic response (LeBlanc et al., 2009).

The derived experimental $p-y$ data were implemented into the program Oasys ALP (hereinafter referred to as ALP; Oasys, 2013), which models the pile as a series of beam elements and the soil as a series of non-interacting $p-y$ (non-linear) springs located at nodes between the beam elements. The evident agreement between the back-analysis using ALP and experimental response provides confirmation of the accuracy of the $p-y$ springs derived.

The experimental results are also compared with the API method (API, 2011) and with the method proposed by Suryasentana \& Lehane (2014) (S\&L method), for which the $p-y$ curves are derived directly from the cone resistance 


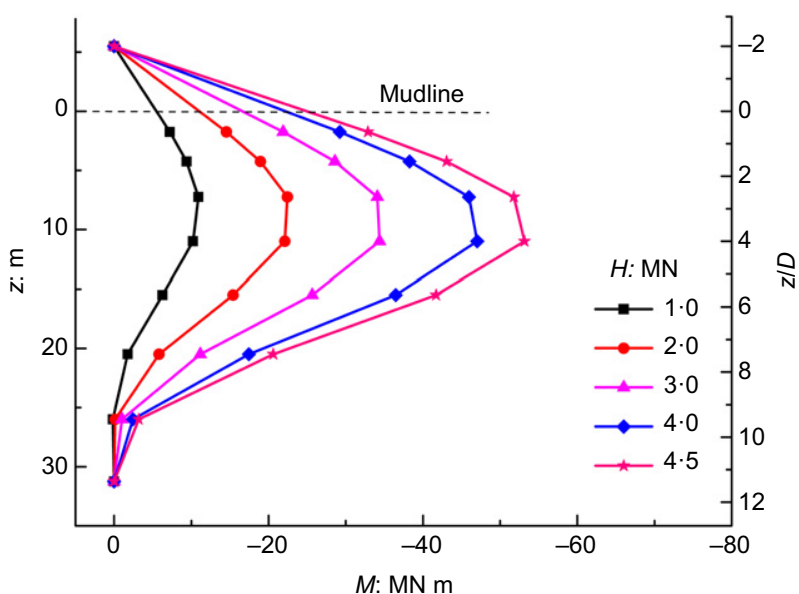

(a)

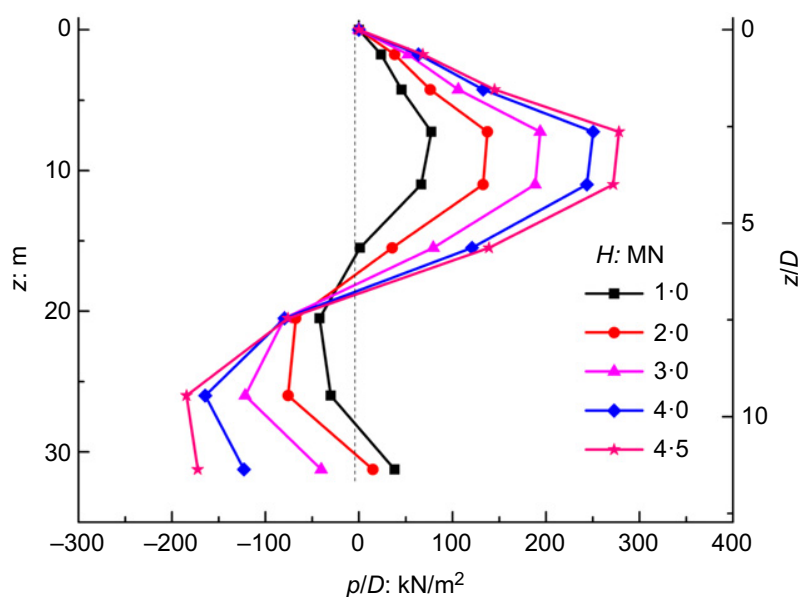

(b)

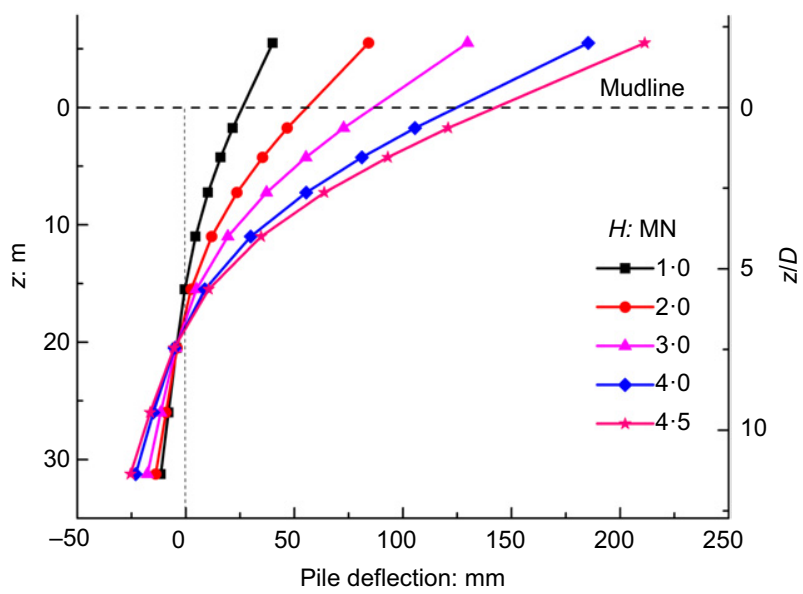

(c)

Fig. 9. Distributions of: (a) bending moment; (b) lateral soil resistance; (c) lateral pile deflection for different values of lateral force (test: pile-1)

profile. As shown in Fig. 11, application of the S\&L method results in a stiffer pile head response, with the displacement measured at the loading position being about 35\% less than in the test. The calculated maximum moment is about $20 \%$ less than that observed experimentally. Centrifuge data presented by Klinkvort et al. (2013) indicate that the pile installation at $1 \mathrm{~g}$ and the smooth epoxy finish on the piles would have contributed to the measured pile response being less stiff than that calculated by the S\&L method.

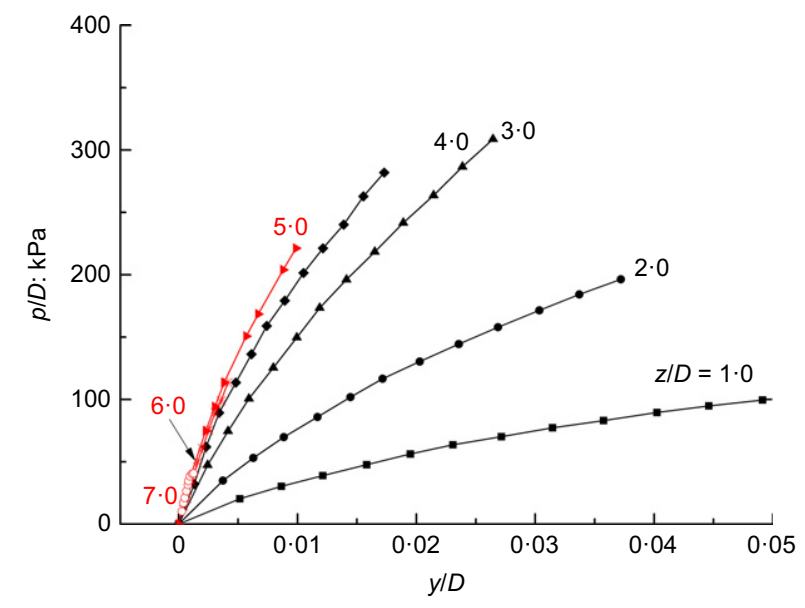

Fig. 10. Experimental $p-y$ curves for different values of soil depth (test: pile-1)

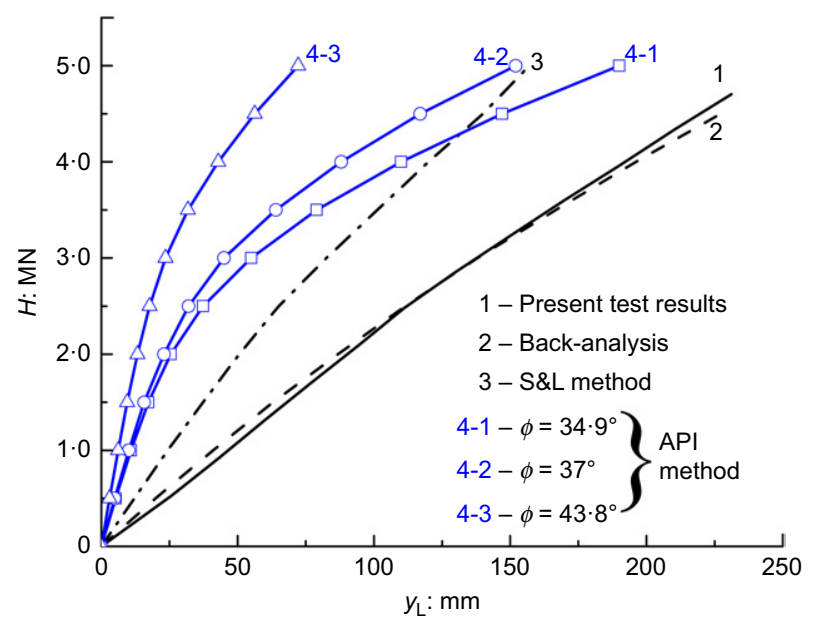

(a)

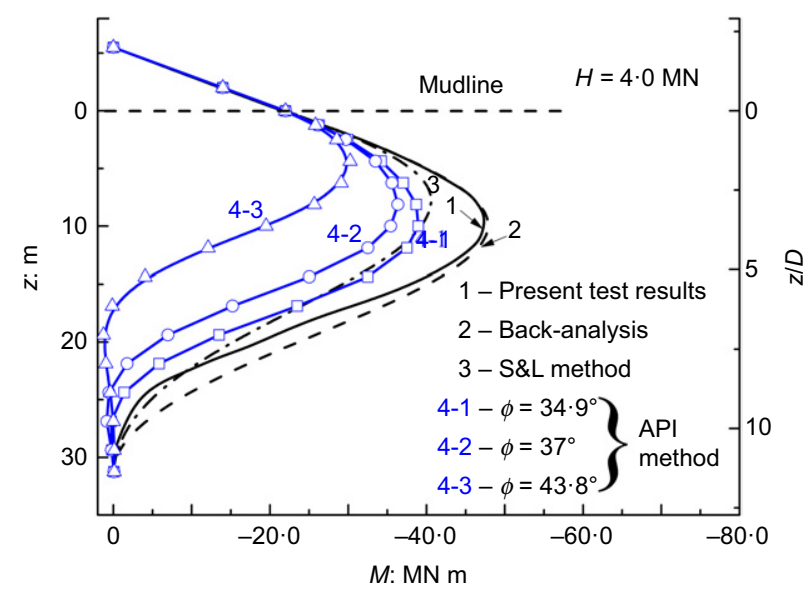

(b)

Fig. 11. Comparisons of: (a) load-displacement curves; (b) bending moment profiles (test: pile-1)

The only crucial soil parameter in the API method is the internal friction angle $\phi^{\prime}$, the value of which is affected by many factors (e.g. stress state, relative density). Some underlying uncertainty of the value of $\phi^{\prime}$ remains for the soils in the centrifuge tests. Three representative values of $\phi^{\prime}$ were adopted in the present analyses. The first value of $\phi^{\prime}$ was set as the critical state angle of the UWA sand $\phi_{\text {crit }}$, that is, $\phi^{\prime}=34.9^{\circ}$ (Cheong, 2002). The second value of $\phi^{\prime}=37^{\circ}$ 
was estimated from the measured distribution of the relative density $\left(D_{\mathrm{r}} \approx 0.68\right)$ according to the relationship between $\phi^{\prime}$ and $D_{\mathrm{r}}$ (API, 2011). The third value was estimated using the relationships proposed by Bolton (1986)

$$
\begin{aligned}
& \phi-\phi_{\text {crit }}=3 I_{\mathrm{R}} \\
& I_{\mathrm{R}}=D_{\mathrm{r}}\left(10-\ln p^{\prime}\right)-1
\end{aligned}
$$

in which $I_{\mathrm{R}}$ is the relative dilatancy index, and $p^{\prime}$ is the mean effective stress taken at a depth of $10 \mathrm{~m}\left(p^{\prime}=\left(1+2 K_{0}\right) \gamma^{\prime} z / 3=\right.$ $63.5 \mathrm{kPa})$, where the maximum moment occurs. Combined with the conditions of $D_{\mathrm{r}}=0.68$ and $\phi_{\text {crit }}=35^{\circ}$, a value of $\phi^{\prime}=43 \cdot 8^{\circ}$ is obtained.

The pile responses calculated with the API method adopting three different values of $\phi^{\prime}$ are compared with the test results in Fig. 11. For all three values of $\phi^{\prime}$, the measured and back-analysed (using the $p-y$ curves fitted to those measured) pile head responses are less stiff than those using the API method, and also compared with those using the S\&L method. These differences do not affect inferences made in the following from relative $p-y$ comparisons before and after scour.

\section{EFFECTS OF SCOUR \\ General scour}

Figure 12(a) shows the load-displacement curves observed experimentally and those of the ALP back-analysis using correspondingly derived $p-y$ curves for different depths of general scour. The geometries of the pile arrangement (pile embedment depth and load eccentricity) are exactly the same for the three tests (see Fig. 6), which means the only difference between these tests is the overconsolidation of the soil. As shown in Fig. 12(a), no significant difference is evident in the results. The bending moment profiles shown in Fig. 12(b) further confirm the conclusion that general scour has minimal effect on the lateral pile response if the pile embedment depth and load eccentricity are maintained constant.

The $p-y$ curves derived at various depths below the scour base for the tests with general scour are compared with the benchmark pile test without scour in Fig. 13. The $p-y$ curves at a given depth below the scour base generally remain constant for different depths of general scour. In other words, general scour has very little effect on the $p-y$ curves for a given depth relative to the current mudline.

The independence of the $p-y$ curves with respect to the depth of general scour is consistent with the independence of the cone resistance for a given relative depth, $z^{\prime}$, as shown in Fig. 7. This confirms that the degree of overconsolidation has little or no effect on the soil resistance and provides support to the use of CPT-based formulations for $p-y$ curves.

In practice, the main effects of general scour are therefore to reduce the pile embedment and increase the eccentricity of the loading point, while the $p-y$ curves for a given depth, $z^{\prime}$, are unchanged. To confirm this, the previously obtained $p-y$ curves shown in Fig. 10 were implemented into ALP to model the effect of general scour on the lateral pile response. The original embedment and loading eccentricity were taken as those for test pile-1, but were then varied according to each scour depth. The results are presented in Fig. 14, which shows that general scour has a dramatic effect on the lateral pile response for the relatively low initial embedment ratios $(31 \cdot 25 / 2 \cdot 75=11 \cdot 4$, reducing to $8 \cdot 6$ for the maximum scour depth) considered here. A general scour depth of $2.5 \mathrm{~m}(0.9 \mathrm{D})$ was sufficient to almost double the pile deflection.

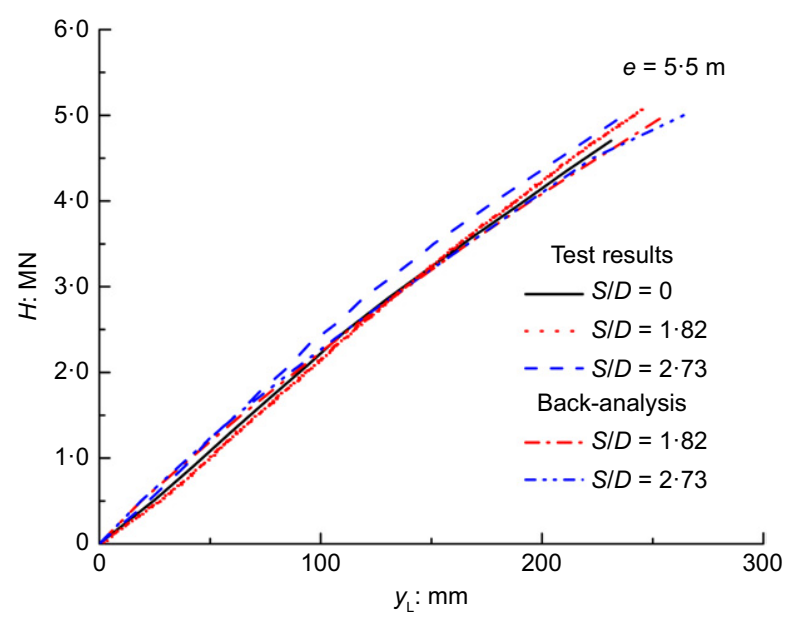

(a)

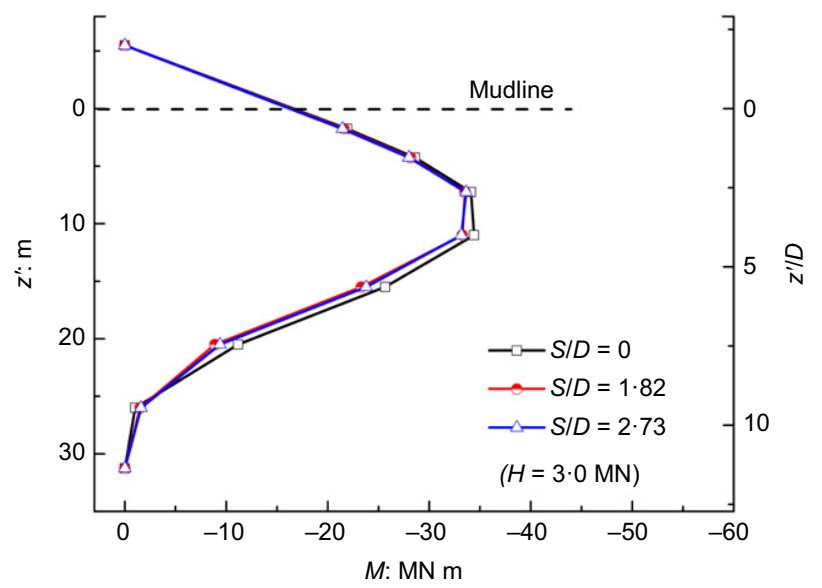

(b)

Fig. 12. Comparisons of: (a) load-displacement curves; (b) bending moment profiles for various values of the general scour depth (tests: pile-1, pile-5, pile-6, pile-7)

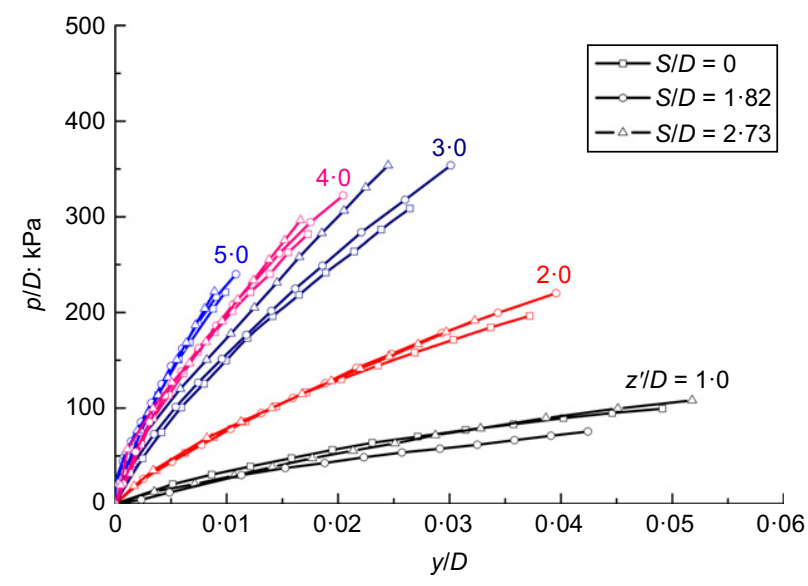

Fig. 13. Comparison of $p-y$ curves for different values of general scour depth (tests: pile-1, pile-6, pile-7)

\section{Local scour}

Figure 15(a) shows the load-displacement curves observed experimentally and those back-analysed using ALP based on the experimentally derived $p-y$ curves for two different depths of local scour, along with the benchmark pile test without scour. For the three tests shown in Fig. 15, the pile embedment and load eccentricity varied with scour depth (see Fig. 6). Fig. 15(a) indicates that the stiffness of the pile 


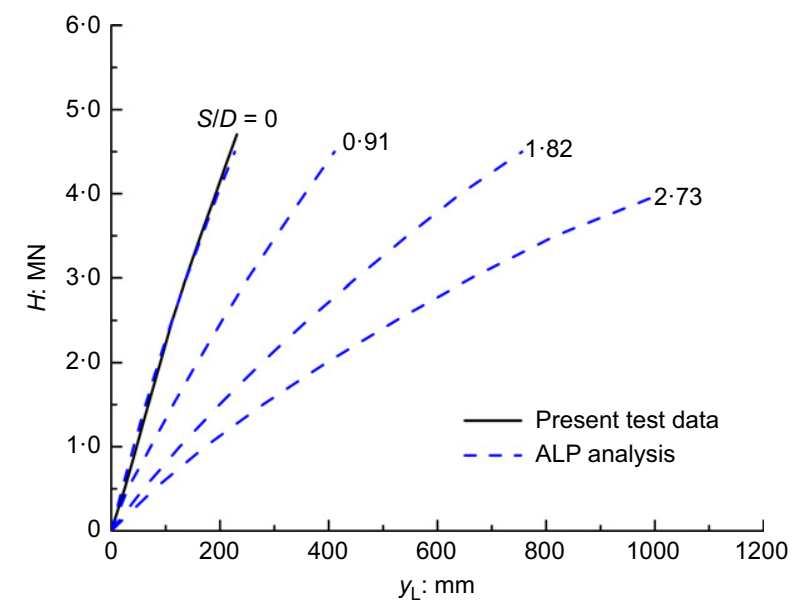

Fig. 14. Effect of general scour on the load-displacement curves of the pile

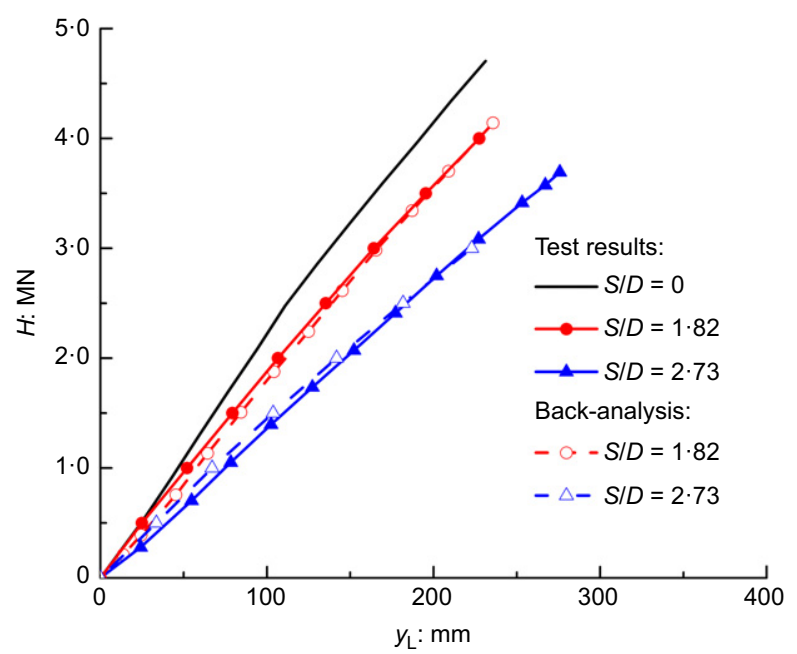

(a)

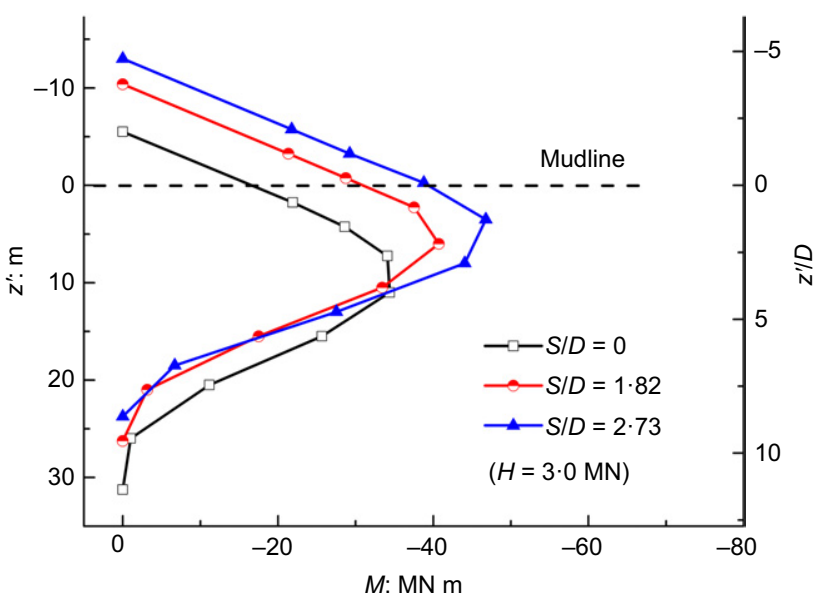

(b)

Fig. 15. Comparison of: (a) load-displacement curves; (b) bending moment profiles for different values of local scour depth (tests: pile-1, pile-3, pile-4)

response decreased significantly with scour depth, and at an increasing rate. However, the increase of pile deflection resulting from local scour is much less than that from general scour, comparing Figs 15(a) and 14, which indicates that the local scour hole dimensions are important. The lateral pile

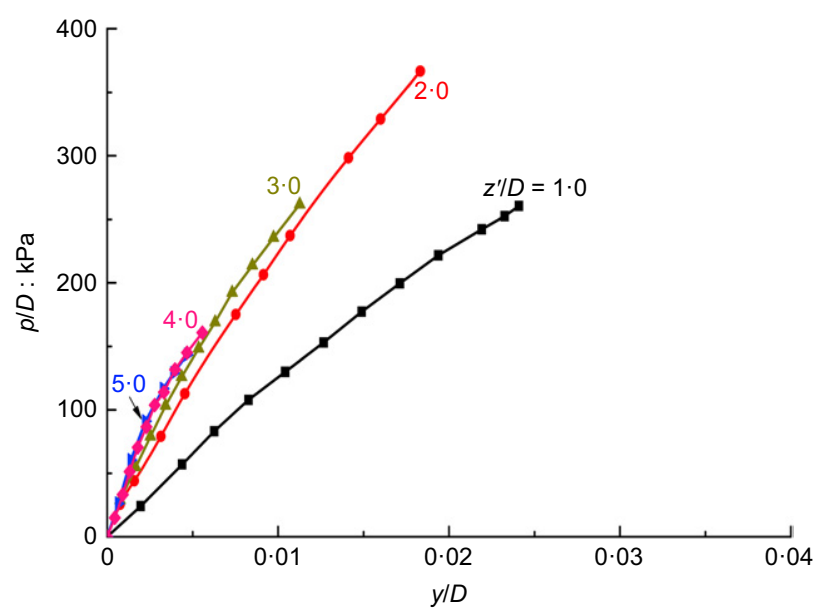

(a)

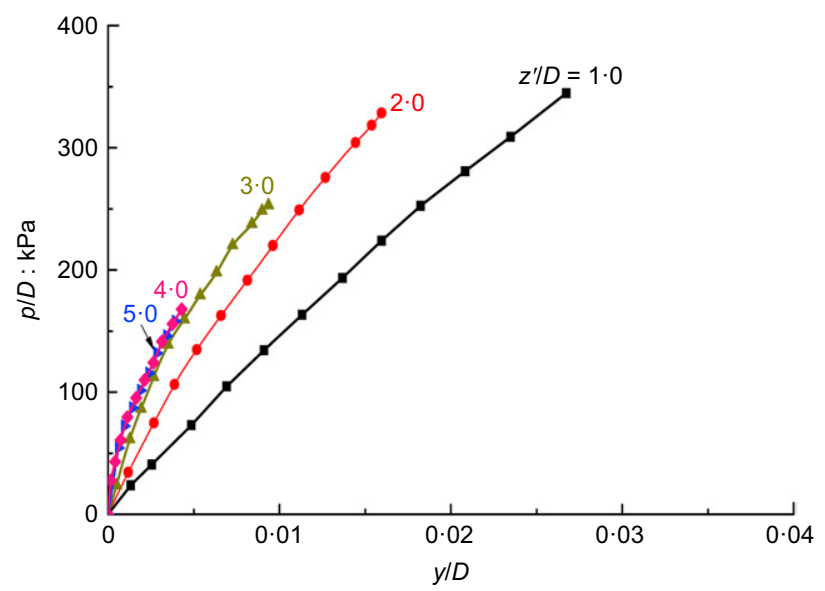

(b)

Fig. 16. Comparison of $p-y$ curves at different values of soil depth below the scour base for various values of the local scour depth: (a) $S I D=1.82$; (b) $S I D=2.73$ (tests: pile-3, pile-4)

displacements would be significantly overestimated if the local scour hole dimensions were ignored (i.e. assuming general scour with removal of the whole soil layer above the maximum scour depth).

Figure 15(b) shows the bending moment profiles for different depths of local scour. For a given value of lateral force, both the moment at ground level and the maximum moment increase. The depth of maximum moment relative to the base of the scour hole becomes shallower with increasing depth of local scour, but slightly deeper in absolute terms.

The derived $p-y$ curves at various soil depths below the scour base for the tests with different local scour depths are compared in Fig. 16, relative to those with no scour in Fig. 10. The $p-y$ curves become significantly stiffer with increasing depth of local scour, especially at relatively shallow depths (e.g. $z^{\prime} / D \leq 3$ ).

The stiffer $p-y$ curves resulting from local scour can be partially explained by the increase of soil resistance for a given $z^{\prime}$ shown in Fig. 8(b). Another important contribution is that the ultimate soil resistance based on a wedge type of failure in a scour hole condition will be larger than for a flat soil surface (Lin et al., 2014).

\section{Evaluation of scour effect: effective soil depth}

As a practical approach to incorporate effects of scour on the $p-y$ curves, an effective soil depth $\left(z_{\mathrm{e}}\right)$ is introduced in the 
following dimensionless expression

$$
\frac{z_{\mathrm{e}}}{D}=\frac{z^{\prime}}{D}+\tanh \left(f \frac{z^{\prime}}{D}\right) \frac{S}{D} \quad\left\{\begin{array}{l}
f \approx 1.5 \text { for local scour } \\
f=0 \text { for general scour }
\end{array}\right.
$$

where the effective soil depth $z_{\mathrm{e}}$ is a weighted-average soil depth relative to the original mudline $z$ and the soil depth below the current scour base $z^{\prime}(=z-S$, see Fig. 1); $f$ is an empirical parameter indicating the transition rate for the effective soil depth from $z_{\mathrm{e}}=z^{\prime}$ at the current mudline to $z_{\mathrm{e}} \approx z$ as the depth increases. According to the comparison of $p-y$ curves and load-displacement curves between the centrifuge tests and the ALP analysis from the calculated effective soil depth, the value of $f$ is optimised as $f \approx 1.5$.

The recommended expression of effective soil depth for local scour cases (see equation (5)) indicates that, at relatively shallow soil depths, the soil resistance is substantially compromised by scour, that is, $z_{\mathrm{e}}$ is closer to $z^{\prime}$; whereas at larger relative soil depths, the soil resistance is barely affected by scour, that is, $z_{\mathrm{e}}$ is closer to $z$. For such local scour cases, the remaining sloping overburden soil around the pile has a significant effect on the $p-y$ curves, that is, the lateral soil stiffness at a given depth below the scour base is greater than that at the same relative depth below the original mudline.

For general scour cases, the results of the present centrifuge tests (see Fig. 13) show that the general scour has only a minor effect on the $p-y$ curves for the same location relative to the current mudline along the whole pile embedment depth. As such, the value of soil depth below the scour base $\left(z^{\prime}\right)$ can be employed directly for determining the $p-y$ curves of the remaining soil. This is equivalent to setting the value of $f$ to zero in equation (5), resulting in $\mathrm{z}_{\mathrm{e}} / D=z^{\prime} / D$ for general scour cases. Even though general scour might, in practice, have a small effect on the $p-y$ curves at a given soil depth, due to overconsolidation effects that might not have been captured by the present modelling technique, owing to the need to stop the centrifuge, the calculated lateral pile deflection would be conservative by adopting $f=0$.

For a given scour depth $(S)$, the values of the effective depth $\left(z_{\mathrm{e}}\right)$ corresponding to various soil depths below the scour base can be obtained with equation (5). Then the $p-y$ data of the benchmark test (pile-1) at the calculated effective soil depths are employed to calculate the lateral pile response for the scour cases. In general, the $p-y$ curves are expressed with a formula consisting of soil depth and soil parameters quantifying soil resistance. Using the effective soil depth approach, the values of the soil parameters quantifying soil resistance should be adjusted to the values at the effective soil depth accordingly.

The dimensionless effective soil depths $\left(z_{\mathrm{e}} / D\right)$ corresponding to the $p-y$ curves in Fig. 10 (for $S / D=0$ ) and Fig. $16(S / D=1.82$ and 2.73$)$ are calculated according to equation (5), as shown in Fig. 17. The $p-y$ curves become progressively stiffer with ascending values of $z_{\mathrm{e}} / D$, with a single exception for $z_{\mathrm{e}} / D=3 \cdot 81\left(S / D=1 \cdot 82, z^{\prime} / D=2\right)$, which shows a slight deviation from the general trend of $p-y$ curves with $z_{\mathrm{e}} / D$. Therefore, the present effective soil depth $\left(z_{\mathrm{e}}\right)$ can reasonably reflect the local scour effect (for a $30^{\circ}$ side slope) on the $p-y$ curves. The $p-y$ curves for various local scour depths are obtained according to the calculated effective soil depth with equation (5) and implemented into ALP. The results of the ALP analysis based on the effective soil depth match well with the test results (see Fig. 18).

The scour-induced amplification of the lateral pile deflection is calculated in ALP according to the effective soil depth. The results are shown in Fig. 19, in which the parameter $y_{\mathrm{L} 0}$ represents the lateral pile deflection at the loading position for the condition without scour. It is shown that the lateral

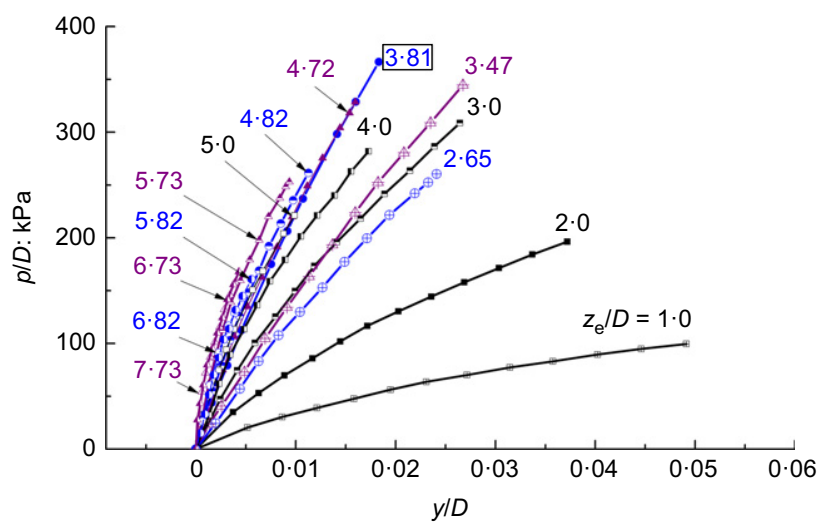

Fig. 17. Variation of $p-y$ curves with ascending values of effective soil depth (tests: pile-1 (curves denoted by squares, i.e. $z_{\mathrm{e}} I D=1 \cdot 0,2 \cdot 0,3 \cdot 0$, $4 \cdot 0,5 \cdot 0)$, pile-3 (curves denoted by circles, i.e. $z_{\mathrm{e}} I D=2 \cdot 65,3 \cdot 81,4 \cdot 82$, $5 \cdot 82,6 \cdot 82$ ), pile-4 (curves denoted by triangles, i.e. $z_{\mathrm{e}} / D=3 \cdot 47,4 \cdot 72$, $5 \cdot 73,6 \cdot 73,7 \cdot 73)$ )

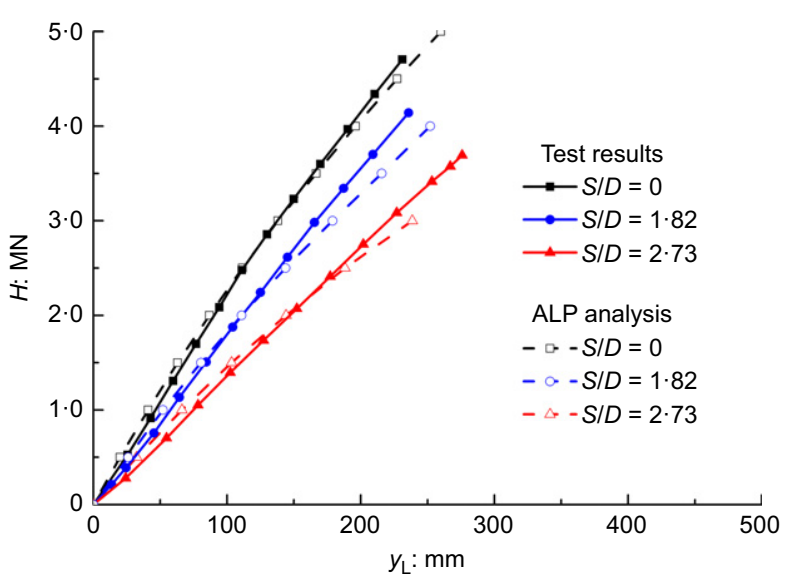

Fig. 18. Comparison of force-displacement curves for local scour conditions from tests and ALP analysis according to the effective soil depth

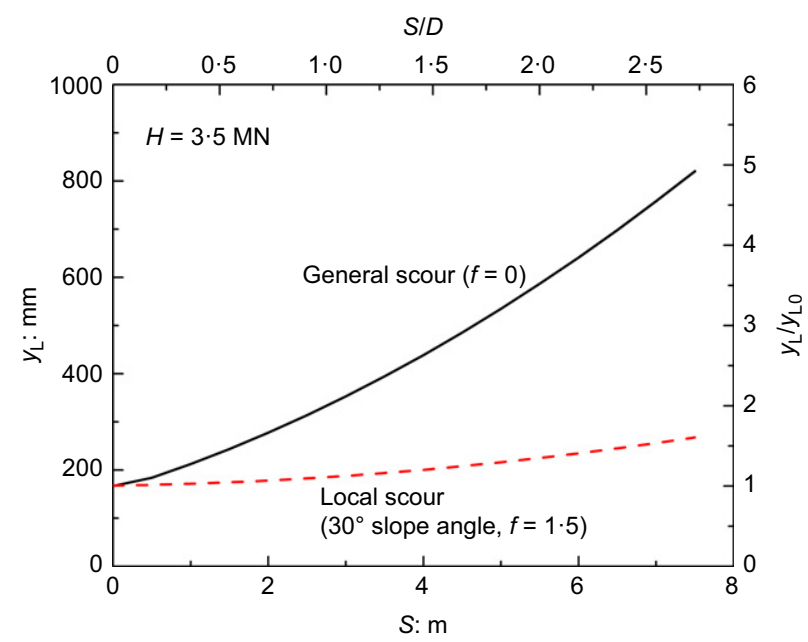

Fig. 19. Scour-induced amplification of the lateral pile deflection (pile diameter, $D=\mathbf{2 . 7 5} \mathrm{m}$, initial embedment depth without scour, $L=31 \cdot 25 \mathrm{~m}$, initial load eccentricity without scour, $e=5.5 \mathrm{~m}$, pile bending stiffness, $\mathrm{EI}=88 \cdot 1 \mathrm{GNm}^{2}$ )

pile deflection amplifies at an accelerating rate with increasing scour depth for both general scour and local scour. However, the rate of amplification induced by local scour is 


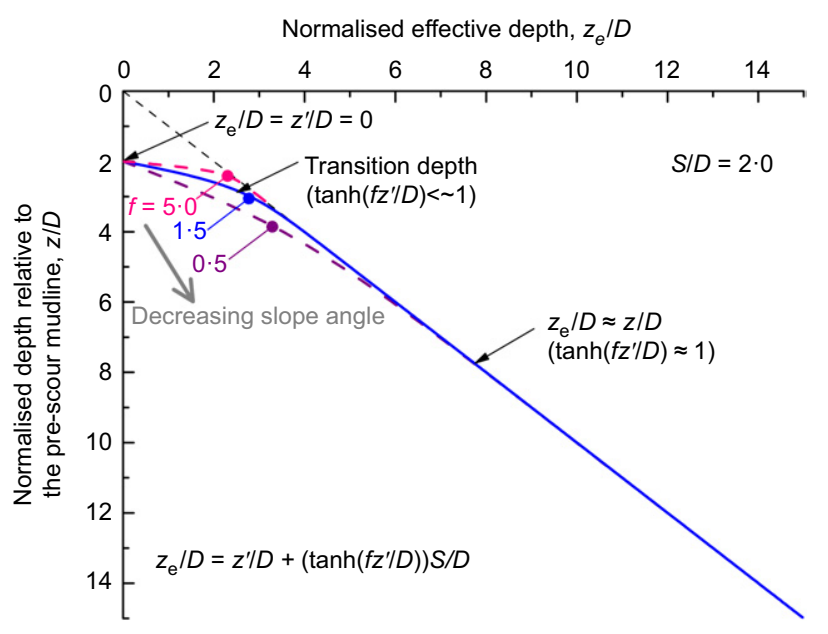

Fig. 20. Illustration of effect of parameter $f$ on calculation of effective soil depth, $z_{\mathrm{e}}$

rather moderate, compared with the dramatic effect of general scour.

Note that, in real ocean environments, both general scour and local scour may occur around a pile foundation under live bed conditions. For such cases, the general scour depth and local scour depth should be quantified separately when evaluating the scour effect on the lateral pile response. Essentially, general scour can be regarded as a special case of local scour with a slope angle of $0^{\circ}$. The slope angle of the scour hole may influence the calculation of $z_{\mathrm{e}}$, in particular, the value of $f$ in equation (5). For the present typical local scour tests with $30^{\circ}$ slope angle, the value of $f=1.5$ implies a transition depth of $z^{\prime} / D \approx 1 \cdot 5$, that is, $z_{\mathrm{e}} / D$ is approximately equal to $z / D$ for $z^{\prime} / D>\sim 1 \cdot 5$. As the slope angle of the scour hole decreases, the effect of the sloping overburden soil above the level of the scour base reduces and the transition depth becomes larger, which means the value of $f$ should be reduced accordingly (see Fig. 20).

\section{CONCLUSIONS}

Scour around a pile may lead to a significant reduction in the lateral stiffness and capacity of the pile, and hence the safety of the superstructure. A series of centrifuge model tests were conducted at a scale of 1:250 to investigate the scour effect on the lateral pile responses. Two types of scour (general scour over the full soil domain, and local scour concentrated just around the pile) were examined in the investigation. Load transfer $p-y$ curves have been derived based on the measured moment distributions and forcedisplacement curves of the pile head. The following conclusions can be drawn.

(a) General scour mainly changes the pile embedment depth and the load eccentricity. For a given depth relative to the current mudline, the $p-y$ curves for the remaining overconsolidated soil after general scour show no obvious difference from those for the original normally consolidated soil.

(b) Local scour reduces the pile embedment depth and increases the load eccentricity (relative to the base of the scour hole). The $p-y$ response at a given soil horizon is only affected at shallow depths and, for most of the profile, the lateral soil stiffness at a given depth below the scour base is greater than that at the same relative depth below the original mudline. The different effects of general scour and local scour can be attributed to the beneficial influence of the remaining overburden soil surrounding the pile in the latter case. Assuming the removal of the whole soil layer above the scour depth is conservative for assessing the effect of scour on the lateral pile response.

(c) The concept of an effective soil depth is introduced to allow determination of $p-y$ curves for the scoured condition. The effective soil depth $z_{\mathrm{e}}$ is a weighted average value of the soil depth relative to the pre-scour mudline $z$ and the soil depth below the current scour base $z^{\prime}$. The parameter $f$ for calculating $z_{\mathrm{e}}$ (see equation (5)) reflects the rate of transition of $z_{\mathrm{e}}$ from $z_{\mathrm{e}}=z^{\prime}$ at the current mudline to $z_{\mathrm{e}} \approx z$ as the depth increases. The recommended values of $f$ are $f=0$ for general scour conditions, and $f \approx 1.5$ for typical local scour conditions with a $30^{\circ}$ slope angle of the scour hole. The results calculated according to the proposed effective soil depth have been shown to provide a reasonable estimation of the effect of scour on $p-y$ curves for laterally loaded piles.

A caveat regarding the above conclusions is that the experimental approach necessitated stopping the centrifuge in order to create each scour hole (or general scour), which may have resulted in lower post-scour horizontal stresses than would otherwise be the case. However, the proposed effective soil depths are considered to offer a straightforward, albeit potentially conservative, approach to evaluate the effects of scour.

\section{ACKNOWLEDGEMENTS}

This work is financially supported by Australia-China Natural Gas Technology Partnership Fund, National Natural Science Foundation of China (grant no. 11232012) and the National Basic Research Program of China ('973' Project) (grant no. 2014CB046204). Technical assistance in the centrifuge tests from the technicians of the Centre for Offshore Foundation System at UWA, is greatly appreciated. The authors would also like to acknowledge Pauline Truong of UWA whose advice and support were invaluable.

$\begin{aligned} & \text { NOTATION } \\ & C_{1} \quad \text { integration constant } \\ & C_{2} \text { integration constant } \\ & c_{\mathrm{v}} \text { sand consolidation coefficient } \\ & D \text { pile diameter } \\ & D_{\mathrm{r}} \text { relative density } \\ & d_{50} \text { mean size of sand grains } \\ & d_{\text {cone }} \text { diameter of cone penetrometer } \\ & E_{\mathrm{p}} I_{\mathrm{p}} \text { bending stiffness of pile section } \\ & e \text { initial load eccentricity } \\ & e^{\prime} \text { post-scour load eccentricity } \\ & f \text { empirical parameter in equation }(5) \\ & H \text { lateral load at pile head } \\ & I_{\mathrm{R}} \text { relative dilatancy index } \\ & K_{0} \text { lateral pressure coefficient } \\ & L \text { initial pile embedment depth } \\ & L^{\prime} \text { post-scour pile embedment depth } \\ & M \text { bending moment } \\ & p \text { lateral soil resistance } \\ & p^{\prime} \text { mean effective stress } \\ & q_{\mathrm{c}} \text { cone penetration end resistance } \\ & S \text { scour depth around piles } \\ & v \text { loading velocity of the lateral force } \\ & y \text { lateral deflection of the pile } \\ & y_{\mathrm{L}} \text { lateral displacement of the pile at the loading position } \\ & z \text { soil depth relative to the pre-scour mudline } \\ & z^{\prime} \text { soil depth below the current scour base } \\ & z_{\mathrm{e}} \text { effective soil depth } \\ &\end{aligned}$

\section{NOTATION}

integration constant

integration constant

sand consolidation coefficient

$e$ initial load eccentricity

$e^{\prime}$ post-scour load eccentricity

$K_{0} \quad$ lateral pressure coefficient

$L \quad$ initial pile embedment depth

mean effective stress

cone penetration end resistance

$S$ scour depth around piles

loading velocity of the lateral force

lateral deflection of the pile

current scour base 
$\gamma^{\prime} \quad$ submerged unit weight of soil

$\sigma_{\mathrm{v} 0}^{\prime} \quad$ vertical effective stress

$\phi^{\prime} \quad$ internal friction angle of soil

$\phi_{\text {crit }}^{\prime} \quad$ critical state angle of soil

\section{REFERENCES}

API (American Petroleum Institute) (2011). Geotechnical and foundation design considerations, ANSI/API recommended practice 2 GEO, 1st edn. Washington, DC, USA: API.

Bolton, M. D. (1986). The strength and dilatancy of sands. Géotechnique 36, No. 1, 65-78, http://dx.doi.org/10.1680/geot. 1986.36.1.65.

Cheong, J. (2002). Physical testing of jack-up footings on sand subjected to torsion. Honours thesis, The University of Western Australia, Crawley, Australia.

Dyson, G. J. \& Randolph, M. F. (2001). Monotonic lateral loading of piles in calcareous sand. J. Geotech. Geoenviron. Engng 127, No. 4, 346-352.

Garnier, J., Gaudin, C., Springman, S. M., Culligan, P. J., Goodings, D. J., Konig, D., Kutter, B. L., Phillips, R., Randolph, M. F. \& Thorel, L. (2007). Catalogue of scaling laws and similitude questions in geotechnical centrifuge modelling. Int. J. Phys. Modelling Geotech. 7, No. 3, 1-23.

Guo, F., Lehane, B. M. \& Ju, J. (2014). Experimentally derived CPT-based $p-y$ curves for soft clay. Proceedings of the $3 r d$ international symposium on cone penetration testing, Las Vegas, NV, USA.

Hoffmans, G. J. C. M. \& Verheij, H. J. (1997). Scour manual. Rotterdam, the Netherlands: A.A. Balkema.

Houlsby, G. T. \& Hitchman, R. (1988). Calibration chamber tests of a cone penetrometer in sand. Géotechnique 38, No. 1, 39-44, http://dx.doi.org/10.1680/geot.1988.38.1.39.

Klinkvort, R. T., Hededal, O. \& Springman, S. M. (2013). Scaling issues in centrifuge modelling of monopiles. Int. J. Phys. Modelling Geotech. 13, No. 2, 38-49.

Kuo, Y. S., Achmus, M. \& Abdel-Rahman, K. (2011). Minimum embedded length of cyclic horizontally loaded monopiles. J. Geotech. Geoenviron. Engng 138, No. 3, 357-363.

LeBlanc, C., Houlsby, G. T. \& Byrne, B. W. (2009). Response of stiff piles in sand to long-term cyclic lateral loading. Géotechnique 60, No. 2, 79-90, http://dx.doi.org/10.1680/geot.7.00196.

Lin, C., Bennett, C., Han, J. \& Parsons, R. L. (2010). Scour effects on the response of laterally loaded piles considering stress history of sand. Comput. Geotech. 37, No. 7-8, 1008-1014.

Lin, C., Han, J., Bennett, C. \& Parsons, R. L. (2014). Analysis of laterally loaded piles in sand considering scour hole dimensions. J. Geotech. Geoenviron. Engng 140, No. 6, 04014024-104014024-13.

Matutano, C., Negro, V., López-Gutiérrez, J. S. \& Esteban, M. D. (2013). Scour prediction and scour protections in offshore wind farms. Renewable Energy 57, 358-365.

Melville, B. W. \& Sutherland, A. J. (1988). Design method for local scour at bridge piers. J. Hydraulic Engng 114, No. 10, $1210-1226$.

Oasys (2013). Oasys ALP: software, version 19.2. Newcastle-uponTyne, UK: Oasys Ltd.
O'Neill, M. W. \& Murchison, J. M. (1983). An evaluation of $p-y$ relationships in sands, report to American Petroleum Institute. Houston, TX, USA: University of Houston.

Qi, W. G. \& Gao, F. P. (2014a). Equilibrium scour depth at offshore monopile foundation in combined waves and current. Sci. China Technol. Sci. 57, No. 5, 1030-1039.

Qi, W. G. \& Gao, F. P. (2014b). Physical modeling of local scour development around a large-diameter monopile in combined waves and current. Coastal Engng 83, 72-81.

Reese, L. C., Cox, W. R. \& Koop, F. D. (1974). Analysis of laterally loaded piles in sand. Proceedings of the offshore technology conference, Houston, TX, paper OTC 2080.

Remaud, D. (1999). Pieux sous charges latérales: étude expérimentale de l'effet de groupe. Doctorate thesis, Université de Nantes, Nantes, France (in French).

Richardson, E. V. \& Davis, S. R. (2001). Evaluating scour at bridges, hydraulic engineering circular no. 18, FHWA-NHI-01-001. Washington, DC, USA: US Department of Transportation, Federal Highway Administration.

Roulund, A., Sumer, B. M., Fredsøe, J. \& Michelsen, J. (2005). Numerical and experimental investigation of flow and scour around a circular pile. J. Fluid Mech. 534, 351-401.

Schneider, J. A. \& Lehane, B. M. (2006). Effects of width for square centrifuge displacement piles in sand. In Proceedings of the 6th international conference on physical modelling in geotechnics (ICPMG) (eds C. W. W. Ng, Y. H. Wang and L. M. Zhang), pp. 868-873. London, UK: Taylor \& Francis.

Stewart, D. P. \& Randolph, M. F. (1991). A new site investigation tool for the centrifuge. In Centrifuge 91: proceedings of the international conference on geotechnical centrifuge modelling (eds H.-Y. Ko and F. G. Mc Lean), pp. 531-538. Rotterdam, the Netherlands: Balkema.

Stewart, D. P., Boyle, R. S. \& Randolph, M. F. (1998). Experience with a new drum centrifuge. In Centrifuge 98: proceedings of the international conference on geotechnical centrifuge modelling (eds T. Kimura, O. Kusakabe and J. Takemura), vol. 1, pp. 35-40. Rotterdam, the Netherlands: Balkema.

Sumer, B. M. \& Fredsøe, J. (2002). The mechanics of scour in the marine environment. Singapore: World Scientific.

Sumer, B. M., Fredsøe, J. \& Christiansen, N. (1992). Scour around a vertical pile in waves. J. Waterway, Port, Coastal, and Ocean Engng 118, No. 1, 15-31.

Suryasentana, S. K. \& Lehane, B. M. (2014). Numerical derivation of CPT-based $p-y$ curves for piles in sand. Géotechnique 64, No. 3, 186-194, http://dx.doi.org/10.1680/geot.13.P.026.

Taylor, R. N. (1995). Geotechnical centrifuge technology. London, UK: Blackie Academic.

Wang, J. \& Qi, C. (2008). $p-y$ curves of piles in saturated degradation sands with residual pore water pressures. In Proceedings of the 18th international offshore and polar engineering conference, Vancouver, Canada (eds J. S. Chung, S. W. Hong, S. Prinsenberg and S. Nagata), pp. 690-697. Cupertino, CA, USA: International Society of Offshore and Polar Engineers (ISOPE).

Yang, K. \& Liang, R. (2006). Methods for deriving $p-y$ curves from instrumented lateral load tests. Geotech. Testing J. 30, No. 1, $31-38$.

Zanke, U. C. E., Hsu, T. W., Roland, A., Link, O. \& Diab, R. (2011). Equilibrium scour depths around piles in noncohesive sediments under currents and waves. Coastal Engng 58, No. 10, 986-991. 